\title{
Preparation of Pd-Ni Nanoparticles Supported on Activated Carbon for Efficient Removal of Basic Blue 3 from Water
}

\author{
Sultan Alam ${ }^{1}$, Muhammad Sufaid Khan ${ }^{1}$, Ali Umar ${ }^{1}$, Rozina Khattak ${ }^{2}$, Najeeb ur Rahman ${ }^{1}$, Ivar Zekker ${ }^{3, *}$, \\ Juris Burlakovs ${ }^{4}\left(\right.$, Sergio S. dC Rubin ${ }^{5,6} \oplus^{\circ}$, Makarand Madhao Ghangrekar ${ }^{7}{ }^{(0}$, Gourav Dhar Bhowmick ${ }^{7}$, \\ Anna Kallistova ${ }^{8}$, Nikolai Pimenov ${ }^{8}$, Abbas Khan ${ }^{9}$ (i) and Muhammad Zahoor ${ }^{10, *(1)}$
}

1 Department of Chemistry, University of Malakand, Chakdara 18800, Pakistan; dr.sultanalam@yahoo.com (S.A.); sufaidkhan1984@gmail.com (M.S.K.); aliumar3937@gmail.com (A.U.); nrnajeeb@yahoo.com (N.u.R.)

2 Department of Chemistry, Shaheed Benazir Bhutto Women University, Peshawar 25000, Pakistan; rzkhattak@yahoo.com

3 Faculty of Science, Institute of Chemistry, University of Tartu, 14 Ravila St., 50411 Tartu, Estonia

4 Department of Water Management, Estonian University of Life Sciences, 5 Kreutzwaldi St., 51014 Tartu, Estonia; Juris.burlakovs@emu.ee

5 Georges Lamaitre Center for Earth and Climate Research, Earth and Life Institute, Université Catholique de Louvain, B-1348 Louvain, Belgium; sergio.rubin@uclouvain.be

6 Centro Nacional de Investigaciones Biotecnológicas (CNIB), 429 Cala Cala, Cochabamba 2500, Bolivia

7 Department of Agricultural and Food Engineering, Indian Institute of Technology Kharagpur, Kharagpur 721302, India; ghangrekar@civil.iitkgp.ernet.in (M.M.G.); gourav.db@gmail.com (G.D.B.)

check for updates

Citation: Alam, S.; Khan, M.S.; Umar, A.; Khattak, R.; Rahman, N.u.; Zekker, I.; Burlakovs, J.; Rubin, S.S.d.; Ghangrekar, M.M.; Bhowmick,

G.D.; et al. Preparation of Pd-Ni Nanoparticles Supported on Activated Carbon for Efficient Removal of Basic Blue 3 from Water. Water 2021, 13, 1211. https:// doi.org/10.3390/w13091211

Academic Editor: Zacharias Frontistis

Received: 1 April 2021

Accepted: 25 April 2021

Published: 27 April 2021

Publisher's Note: MDPI stays neutral with regard to jurisdictional claims in published maps and institutional affiliations.

Copyright: (c) 2021 by the authors. Licensee MDPI, Basel, Switzerland. This article is an open access article distributed under the terms and conditions of the Creative Commons Attribution (CC BY) license (https:// creativecommons.org/licenses/by/ $4.0 /)$.
8 Research Centre of Biotechnology of the Russian Academy of Sciences, Winogradsky Institute of Microbiology, Leninsky Prospect, 33, Build. 2, 119071 Moscow, Russia; kallistoanna@mail.ru (A.K.); npimenov@mail.ru (N.P.)

9 Department of Chemistry, Abdul Wali Khan University, Mardan 23200, Pakistan; abbas053@gmail.com

10 Department of Biochemistry, University of Malakand, Chakdara 18800, Pakistan

* Correspondence: ivar.zekker@ut.ee (I.Z.); mohammadzahoorus@yahoo.com (M.Z.)

Abstract: Pd-Ni nanoparticles supported on activated carbon ( $\mathrm{Pd}-\mathrm{Ni} / \mathrm{AC})$ were prepared using a phase transfer method. The purpose of synthesizing ternary composites was to enhance the surface area of synthesized Pd-Ni nanoparticles, as they have a low surface area. The resulting composite was characterized by scanning electronic microscopy (SEM), X-ray diffraction (XRD) and energy-dispersive X-ray spectroscopy (EDX) for investigating its surface morphology, particle size, percentage of crystallinity and elemental composition, respectively. The XRD data and EDX analysis revealed the presence of $\mathrm{Pd}-\mathrm{Ni}$ alloys impregnated on the $\mathrm{AC}$. Pd-Ni/AC was used as an adsorbent for the removal of the azo dye basic blue 3 from an aqueous medium. Kinetic and isotherm models were used to calculate the adsorption parameters. The most suitable kinetic model amongst the applied models was the pseudo-second-order model, confirming the chemisorption characteristics of the process, and the most suitable isotherm model was the Langmuir model, with a maximum adsorption capacity of $333 \mathrm{mg} / \mathrm{g}$ at $333 \mathrm{~K}$. Different experimental parameters, such as the adsorbent dosage, $\mathrm{pH}$, temperature and contact time, were optimized. The optimum parameters reached were: a $\mathrm{pH}$ of 12 , temperature of $333 \mathrm{~K}$, adsorbent dosage of $0.01 \mathrm{~g}$ and optimum contact time of $30 \mathrm{~min}$. Moreover, the thermodynamics parameters of adsorption, such as Gibbs free energy $\left(\Delta \mathrm{G}^{\circ}\right)$, enthalpy $\left(\Delta \mathrm{H}^{\circ}\right)$ and entropy $\left(\Delta \mathrm{S}^{\circ}\right)$, showed the adsorption processes being exothermic with values of $\Delta \mathrm{H}^{\circ}$ equal to $-6.206 \mathrm{~kJ} / \mathrm{mol}$ and being spontaneous with $\Delta \mathrm{G}^{\circ}$ values of -13.297 , -13.780 and $-14.264 \mathrm{~kJ} / \mathrm{mol}$, respectively at 293, 313 and $333 \mathrm{~K}$. An increase in entropy change $\left(\Delta \mathrm{S}^{\circ}\right)$ with a value of $0.0242 \mathrm{~kJ} / \mathrm{mol} \mathrm{K}$, indicated the enhanced disorder at a solid-solution interface during the adsorption process. Recycling the adsorbent for six cycles with sodium hydroxide and ethanol showed a decline in the efficiency of the selected azo dye basic blue 3 up to $79 \%$. The prepared ternary composite was found effective in the removal of the selected dye. The removal of other pollutants represents one of the possible future uses of the prepared adsorbent, but further experiments are required. 
Keywords: adsorption; parameters; kinetics models; nanoparticles; characterizations; basic blue 3

\section{Introduction}

Despite the rapid development in water reclamation technologies, water pollution is still a major global problem [1]. Bodies of water have been polluted with harmful chemicals due to rapid industrialization, leading to potable water scarcity [2]. Many pollutants, such as heavy metals, radionuclides, phenols, pesticides, herbicides, antibiotics, dyes, etc. [2-9], are constantly released from industry into the environment. Amongst the mentioned pollutants, dyes are the most hazardous, containing complex unsaturated organic compounds absorbing light in the visible region, thus limiting photosynthesis in aquatic environments $[10,11]$. Synthetic dyes are widely used in the clothing, paper, leather, oil, pharmaceutical and food industries as coloring agents [12]. In the textile industry, over 10,000 tons of dye are used per year, and about $10-15 \%$ of these dyes are in the form of dye residues being released into bodies of water [13]. According to a World Health Organization report, dye contributes about $17-20 \%$ to different pollution sources, and of this percentage, $10-15 \%$ are azo dyes, which, along with other hazardous effects (carcinogenic), have caused hepatotoxicity in animal testing [2-9].

The discharge of colour products into bodies of water adversely affects the aquatic environment due to their non-biodegradable complex molecular structures and their byproducts, especially in azo dyes [14]. Colour byproducts in wastewater effluents can cause toxicity depending on their exposure period and the dye concentration. Dyes absorb and reflect sunlight entering the water and can thus interfere with bacterial growth and inhibit photosynthesis in aquatic plants $[15,16]$. The toxicity of dyes may occur either due to the direct action of the original compound or through its intermediate metabolites, such as naphthalene, benzidine and other aromatic amines. These compounds are byproducts of micro-organisms, and the azo dyes' metabolites are also carcinogenic and mutagenic [17-19]. In human beings, these compounds can cause allergic dermatosis, respiratory diseases, contact dermatitis, asthma, changes in immunoglobulin level and colon and rectum cancer [20-24]. These secondary metabolites can also cause severe genotoxic and phytotoxic effects in plants [25].

Several biological, chemical and physical techniques—such as bacterial, fungal, algal and enzymatic decolorization [26]; phytoremediation; photocatalytic degradation; ozonation; electrolysis; ion exchange; advanced oxidation; membrane filtration; coagulation; flocculation; sonication and adsorption processes- have been used to treat dyes present in wastewater effluents [27-40]. These methods have their own merits, but in terms of versatility and cost, the adsorption process has been found to be superior to other techniques [41-44]. Different adsorbents have been recommended for adsorption of dyes, such as modified alumina, activated clay, activated carbon, kaolinite, bentonite, modified saw dust, fly ash, mesoporous zeolite, metal-organic framework, hydrogels, molecularly imprinted polymer (MIP), metal oxide nanoparticles (NPs), monometallic NPs and bimetallic NPs [45-58].

NPs range in size from 1 to $100 \mathrm{~nm}$, which differs from the bulk material due to their particle size [59]. NPs are widely used in various fields, such as cosmetics, electronics, catalysis, medicine, chemotherapy and water treatment [60-64]. In wastewater treatment, NPs have been used for the removal of pesticides, organic dyes and heavy metals and for the degradation of complex organic pollutants. Various monometallic and bimetallic $\mathrm{NPs}$, such as $\mathrm{Pt}, \mathrm{Au}, \mathrm{Cu}, \mathrm{Fe}-\mathrm{Ni}, \mathrm{Cu}-\mathrm{Ag}$, Fe-Zn, $\mathrm{Mn}-\mathrm{Zn}$ and $\mathrm{Pd}-\mathrm{Fe}$, have been used for the adsorption of dyes [65-72].

Bimetallic nanoparticles (BNPs) that are composed of two different metals, as opposed to monometallic NPs, have drawn the attention of scientists [73]. Comparatively, bimetallic NPs have a large surface area, thus serving as effective catalysts compared with monometallic nanoparticles [74]. Their properties can be further improved to a great extent 
when these bimetallic nanoparticles are loaded on a high surface area material, such as activated carbon, graphene oxide, etc. [61].

In this paper, we have synthesized bimetallic Pd-Ni nanoparticles by a phase transfer method; NPs were then impregnated on activated carbon to enhance the surface area of the overall ternary complex. The morphology (shape and size), elemental composition and percentage of crystallinity were analyzed through different instrumental techniques. The supported bimetallic NPs were used for adsorption of basic blue 3 dye from an aqueous medium. The mechanisms and rate of the adsorption process were investigated by applying different kinetic and isotherm models. Furthermore, the adsorbent material used was regenerated by treatment with suitable eluents to check its reproducibility.

\section{Materials and Methods}

\subsection{Chemicals Used}

The chemicals used in this study were: palladium (II) chloride $\left(\mathrm{PdCl}_{2}\right)$, nickel (II) chloride hexahydrate $\left(\mathrm{NiCl}_{2} \cdot 6 \mathrm{H}_{2} \mathrm{O}\right)$, activated carbon $(\mathrm{AC})$, tetraoctylammonium bromide (TOABr), sodium borohydride $\left(\mathrm{NaBH}_{4}\right)$, oleic acid, oleylamine, potassium hydroxide $(\mathrm{KOH})$, sulphuric acid $\left(\mathrm{H}_{2} \mathrm{SO}_{4}\right)$, sodium hydroxide $(\mathrm{NaOH})$, toluene, ethanol, acetone, chloroform, 2-propanol, n-hexane and hydrochloric acid ( $\mathrm{HCl})$. Basic blue 3 (BB-3) was used as an adsorbate, and its structure is given in Figure 1 while its properties are presented in Table 1. All the chemicals were of analytical grade and were purchased from Sigma-Aldrich (Munich, Germany). The chemicals were used as received without any further purification.

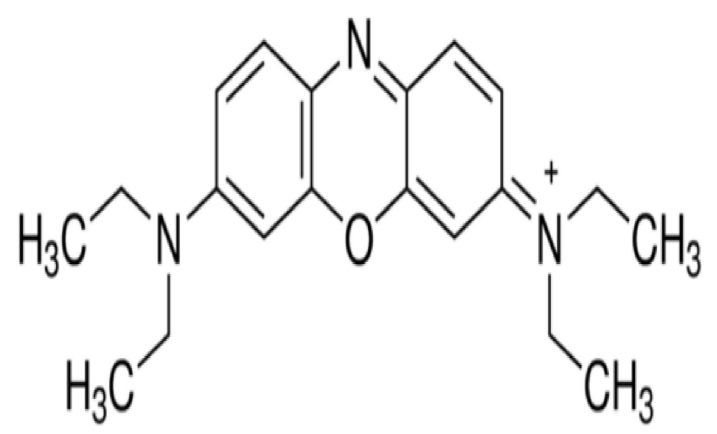

Figure 1. Structure of basic blue 3 .

Table 1. Physiochemical properties of basic blue 3 .

\begin{tabular}{cc}
\hline Name of Dye & Basic Blue 3 \\
\hline Molecular formula & $\mathrm{C}_{20} \mathrm{H}_{26} \mathrm{CIN}_{3} \mathrm{O}$ \\
Molecular Weight & $359.9 \mathrm{~g} / \mathrm{mol}$ \\
$\Lambda_{\max }$ (Maximum wavelength) & 654 \\
\hline
\end{tabular}

\subsection{Instrumentation}

The synthesized adsorbent was characterized by using a $30 \mathrm{KV}$ scanning electron microscope (JSM5910, JEOL, Tokyo, Japan) with an EDX detector (INCA100/Oxford Instruments, Buckinghamshire, UK), X-ray diffractometer (JDX 3532, JEOL, Tokyo, Japan) with SEI and EDX detectors (INCA200/Oxford Instruments, Buckinghamshire, UK), and a $\mathrm{CuK} \alpha$ source. The dye BB-3 concentration was quantified by measuring absorbance with a double beam UV-vis spectrophotometer (UV-1800, Shimadzu Scientific Instruments Inc., Kyoto, Japan) at a wavelength of $654 \mathrm{~nm}$. The solution $\mathrm{pH}$ was determined by using a $\mathrm{pH}$ meter. Adsorption tests were conducted in a thermostatic water-bath shaker.

\subsection{Synthesis of Supported Bimetallic Palladium-Nickel Nanoparticles}

$\mathrm{Pd}-\mathrm{Ni}$ nanoparticles were synthesized in a two-phase liquid system with slight modification in the reported procedure by adding capping agents, such as oleylamine and oleic 
acid [75]. About $5.6 \mathrm{~mL}$ of aqueous solution of $\mathrm{PdCl}_{2}(0.022 \mathrm{M})$ and $5.6 \mathrm{~mL}$ of aqueous solution of $\mathrm{NiCl}_{2}(0.033 \mathrm{M})$ were added to a solution of tetraoctylammonium bromide ( $\mathrm{ToABr}$ ) as a phase-transfer agent in toluene $(0.538 \mathrm{~g}$ of TOABr in $37 \mathrm{~mL}$ of toluene). Then, the solutions were stirred for $2 \mathrm{~h}$. The toluene phase was thereafter separated from the aqueous phase and discarded. The capping agent $(23.4 \mu \mathrm{L}$ of oleic acid and $46 \mu \mathrm{L}$ of oleylamine) was then added to the mixture and was stirred for another $30 \mathrm{~min}$. To reduce the $\mathrm{Pd}^{2+}$ to $\mathrm{Pd}^{0}$ and $\mathrm{Ni}^{2+}$ to $\mathrm{Ni}^{0}, 35 \mathrm{~mL}$ of $\mathrm{NaBH}_{4}$ solution $(0.2 \mathrm{M})$ was drop wise added into the reaction mixture and stirred for $12 \mathrm{~h}$. After completing the process, the Pd-Ni colloidal particles were obtained, which were then washed with a dilute solution of $\mathrm{KOH}(5 \mathrm{mM})$ and distilled water. To support the $\mathrm{Pd}-\mathrm{Ni}$ particles on the activated carbon, $80 \mathrm{mg}$ of powdered activated carbon was added. After the addition of activated carbon, the mixture was stirred for $12 \mathrm{~h}$. Then, the Pd-Ni powder supported on the activated carbon ( $\mathrm{Pd}-\mathrm{Ni} / \mathrm{AC}$ ) was separated and purified with chloroform, acetone, toluene and ethanol [75]. The prepared powders were kept in an oven at $70^{\circ} \mathrm{C}$ for $2 \mathrm{~h}$ and stored in bottles. The summary of the entire procedure is shown in Figure 2.

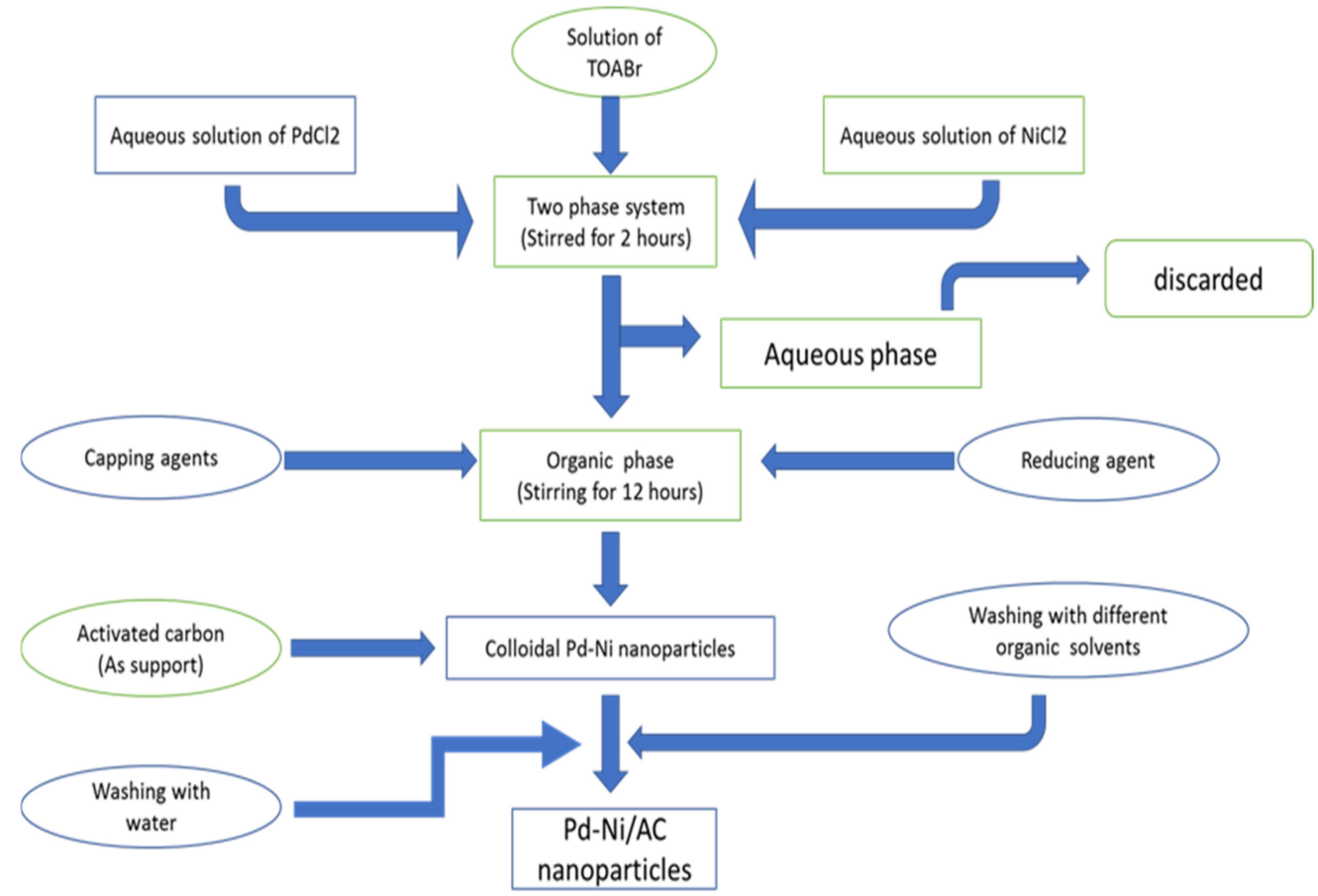

Figure 2. Synthesis of $\mathrm{Pd}-\mathrm{Ni}$ supported on activated carbon.

\subsection{Adsorption Experiments}

The adsorption of basic blue 3 dye on the prepared adsorbent was performed at a $\mathrm{pH}$ of 12 . About $0.01 \mathrm{~g} \mathrm{Pd}-\mathrm{Ni} / \mathrm{AC}$ was mixed with a $10 \mathrm{~mL}$ solution of BB-3 in reagent bottles. The $\mathrm{pH}$ of the solutions was adjusted by the addition of a few drops of $\mathrm{HCl}(0.1 \mathrm{M})$ or $\mathrm{NaOH}(0.1 \mathrm{M})$ based on the requirement of the experiments. The solutions were mixed in a thermostatic water bath shaker for different time intervals. The reagent bottles were removed from the shaker at a predetermined time, the adsorbent was separated and the concentration of BB-3 dye in the filtrate was measured by a UV-vis spectrophotometer at a wavelength of $\lambda \max 654 \mathrm{~nm}$. The dye's concentration was determined based on the calibration curve drawn for a concentration range. The adsorption capacity of adsorbent $\mathrm{q}_{\mathrm{t}}\left(\mathrm{mg} \mathrm{g}^{-1}\right)$ and the removal efficiency were calculated by using Equations (1) and (2), respectively, according to a comparative study performed [76,77]:

$$
\mathrm{q}_{\mathrm{t}}=\frac{\mathrm{C}_{0}-\mathrm{C}_{\mathrm{t}}}{\mathrm{W}} \mathrm{V}
$$




$$
\% \mathrm{R}=\frac{\mathrm{C}_{0}-\mathrm{C}_{\mathrm{t}}}{\mathrm{C}_{0}} \times 100
$$

where $\mathrm{q}_{\mathrm{t}}$ is the amount of dye adsorbed $(\mathrm{mg} / \mathrm{g}), \% \mathrm{R}$ is the percentage of dye removal efficiency, $C_{0}$ is the initial concentration of dye $(\mathrm{mg} / \mathrm{L}), \mathrm{C}_{\mathrm{t}}$ is the concentration of dye after adsorption, $\mathrm{V}$ is the volume of dye solution $(\mathrm{mL})$ and $\mathrm{W}$ is the weight of the adsorbent $(\mathrm{g})$. Various kinetics models were used to enumerate the kinetic constants of adsorption.

Adsorption isotherm experiments were performed on different concentrations, which ranged from $50 \mathrm{mg} / \mathrm{L}$ to $500 \mathrm{mg} / \mathrm{L}$ with $0.01 \mathrm{~g}$ of the prepared adsorbent, while the $\mathrm{pH}$ kept was 12. After the addition of the adsorbent, the solutions were stirred for $1 \mathrm{~h}$. Thereafter, the adsorbent was separated from the solution through filtration, and at $654 \mathrm{~nm}$ the remaining concentrations were determined using a UV-vis spectrophotometer.

Similar effects of adsorbent dosage, $\mathrm{pH}$ and temperature were determined for $100 \mathrm{mg} / \mathrm{L}$ solutions, keeping the other parameters the same as the aforementioned.

\section{Results and Discussion}

\subsection{Characterization of Pd-Ni/AC Morphology and Elemental Composition}

The surface morphology of $\mathrm{Pd}-\mathrm{Ni} / \mathrm{AC}$ was determined by SEM analysis. The SEM images are given in Figure 3a-d. The micrographs show rough interfaces along with many holes and nanoparticles spreading over the material. Overall, the surface shows irregular particle channels for the adsorption of the specified dye.
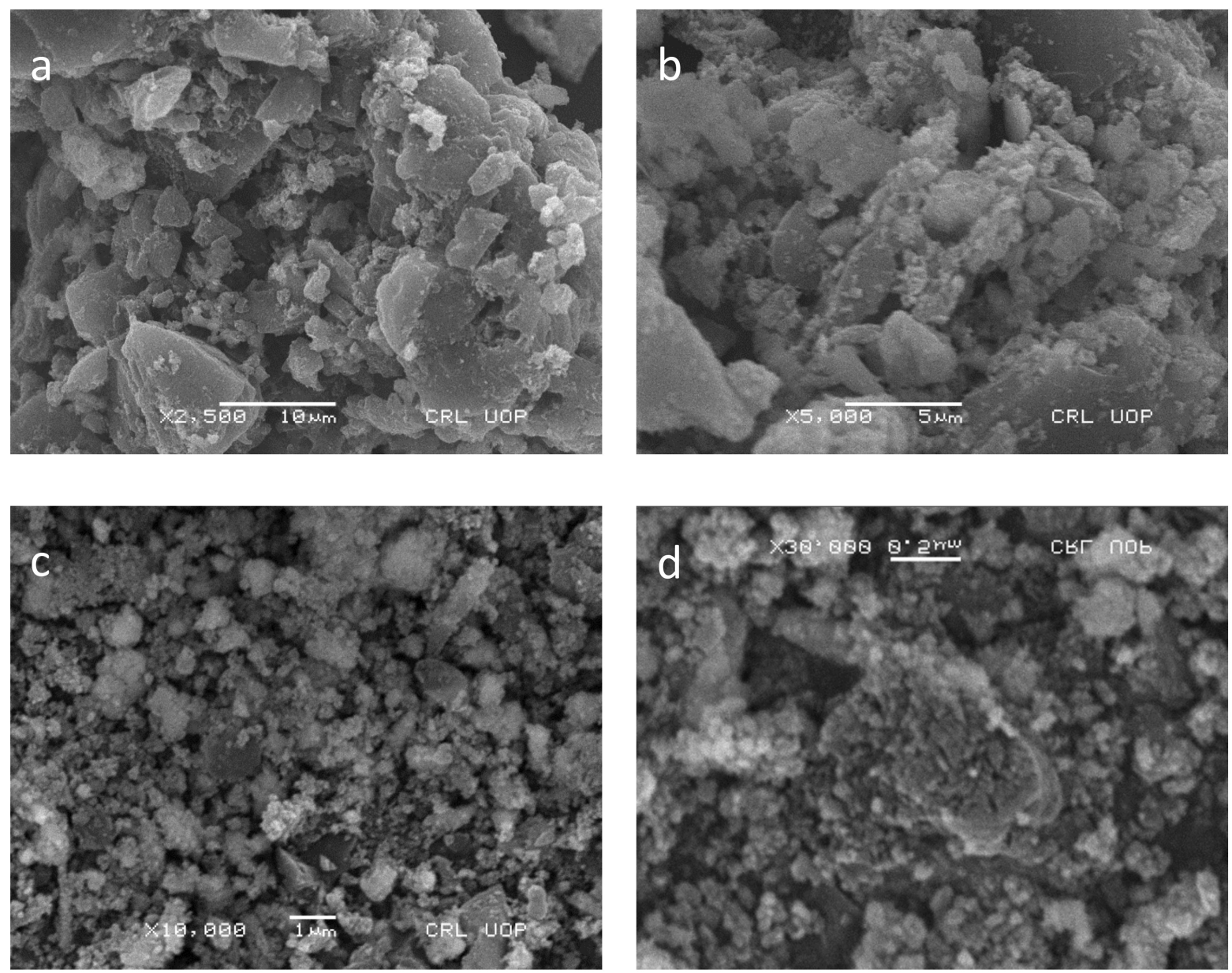

Figure 3. SEM images of Pd-Ni supported on activated carbon at different magnifications of (a) $5000 \times$, (b) $10,000 \times$, (c) $30,000 \times$, (d) $2500 \times$. 
Figure 4a shows the EDX elemental analysis of the prepared adsorbent. The results show that elemental atomic weight percentages of $\mathrm{Pd}-\mathrm{Ni} / \mathrm{AC}$ were found to be: $\mathrm{C}(56.63 \%)$, O (13.56\%), Pd (29.30\%) and Ni (0.51\%). Similarly, Figure 4b presents the XRD pattern for the $\mathrm{Pd}-\mathrm{Ni} / \mathrm{AC}$ adsorbent. According to the Scherer formula, the calculated crystallite size is $7.4 \mathrm{~nm}$ while the crystallinity is determined to be $83 \%$. Moreover, the characteristic peaks confirm the existence of the $\mathrm{Pd}-\mathrm{Ni}$ alloy formation.
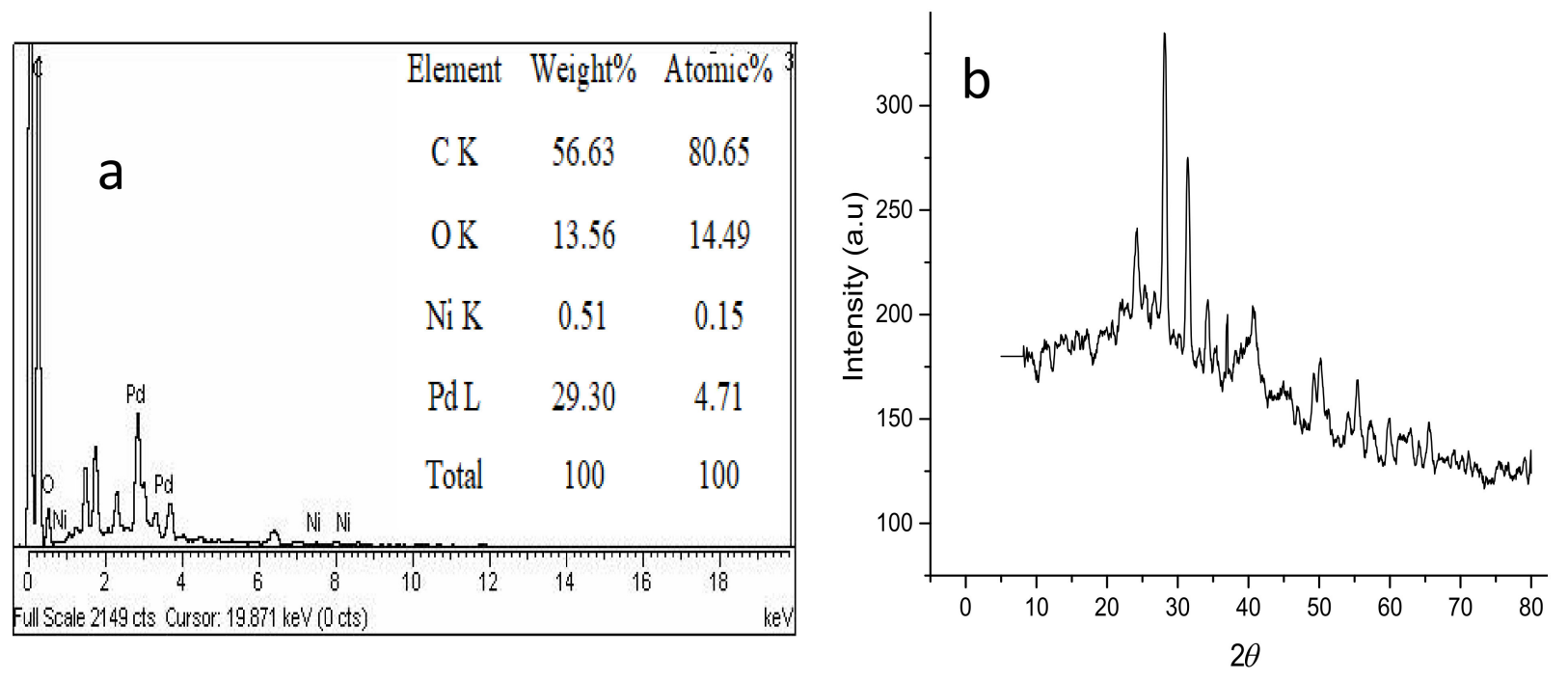

Figure 4. (a) EDX analysis; (b) X-rays Diffraction (XRD) spectrum of the Pd-Ni/AC.

\subsection{Adsorbent Dosage Effect on Adsorption}

Different adsorbent dosages (0.005-0.03 g) were used to find the optimum amount of adsorbent used for BB-3 removal from the aqueous media in the adsorption experiments. The results are shown in Figure 5a, emphasizing that a linear increase occurred in the removal efficiency of dye with an increase in adsorbent dosage up to $0.01 \mathrm{~g}$ of the adsorbent, which was due to the increase of adsorbent surface area and the greater availability of the adsorption active sites. Hence, about $0.01 \mathrm{~g}$ of adsorbent dosage was used as the optimal dosage in the subsequent experiments.

\subsection{Effect of $\mathrm{pH}$ on Adsorption}

The acidic or basic media had a major effect on the nature and charge of the adsorbent, as well as on BB-3 adsorption. BB-3 adsorption was investigated at different $\mathrm{pH}$ levels (1-14). According to Figure $5 \mathrm{~b}$, the maximum dye removal was obtained at $\mathrm{pH}(8-12)$. As the dye is cationic in nature, high $\mathrm{pH}$ favorability was encountered and optimum adsorption values were achieved. The second most contributing factor was soft-soft interaction between the functional groups that were present at the adsorbate and the metal centers at the adsorbent. At high $\mathrm{pH}(8-12)$, electrostatic interaction between the adsorbent and the dye, as well as the dye's metal center interaction, enhanced the BB-3 removal efficiency. At lower $\mathrm{pH}$, the decrease in the removal efficiency of $\mathrm{BB}-3$ might be due to $\mathrm{H}^{+}$ion competition with BB-3 molecules for the adsorption sites at the adsorbent.

\subsection{Effect of Contact Time on Adsorption of BB-3}

It was found that the extent of dye removal was improved by increasing contact time, and a maximum value was reached after $30 \mathrm{~min}$. Figure $5 \mathrm{c}$ demonstrates that after $30 \mathrm{~min}$ contact time, there was no significant effect on dye adsorption observed. Thus, a $30 \mathrm{~min}$ reaction time was considered to be the optimum contact time. 

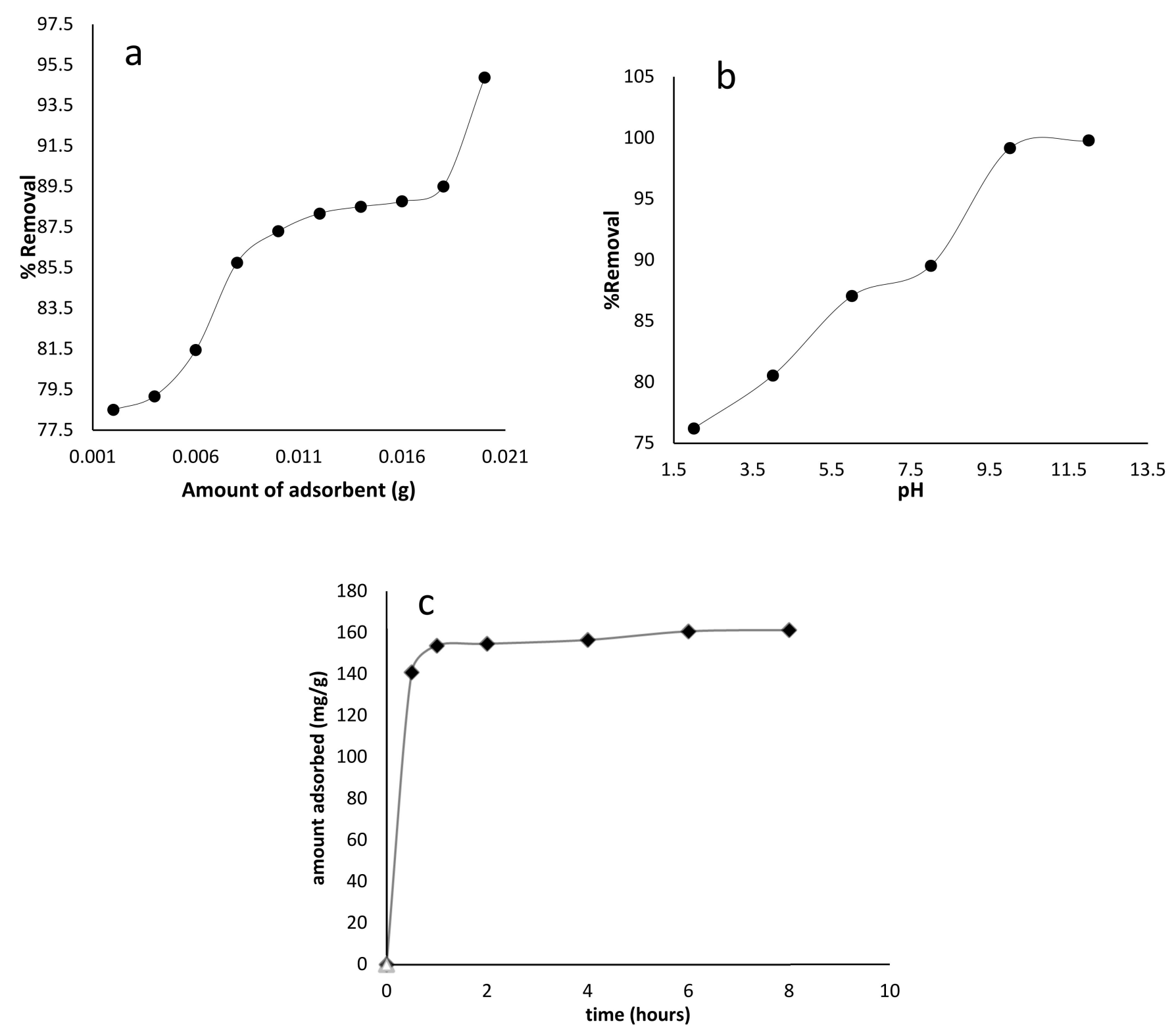

Figure 5. BB-3 adsorption on Pd-Ni/AC with the effects of (a) amount of adsorbent (b) pH and (c) contact time.

\subsection{Adsorption Kinetics of BB-3 Adsorption}

Adsorption kinetics must be considered for understanding the precise adsorption mechanism. Adsorption kinetics were applied for the assessment of adsorbate-adsorbent interaction and adsorption parameters [78]. Different kinetics models were applied to assess the kinetics of BB-3 adsorption on the prepared adsorbent.

The linear form of the pseudo-first-order kinetic equation can be given as follows [76,77]:

$$
\log \left(\mathrm{q}_{\mathrm{e}}-\mathrm{q}_{\mathrm{t}}\right)=\log \mathrm{q}_{\mathrm{e}}-\frac{\mathrm{k}_{1}}{2.303}
$$

In this equation, $\mathrm{k}_{1}\left(\mathrm{~min}^{-1}\right)$ is the equilibrium rate constant, $\mathrm{q}_{\mathrm{e}}$ and $\mathrm{q}_{\mathrm{t}}$ are the amounts of dye adsorbed at equilibrium and $t$ is time. The values of the constants $k_{1}$ and $q_{e}$ were determined from the slope and intercept of the $\log \left(q_{e}-q_{t}\right)$ versus $t$ [79] plot, which is shown in Figure 6a (Table 2).

The correlation coefficient $\mathrm{R}^{2}$ was less than 0.9 , which confirmed that this model did not show the best fit and proved that the sorption process was not a physisorption process. 
The pseudo-second-order kinetic equation was expressed as [76,77]:

$$
\frac{\mathrm{t}}{\mathrm{q}_{\mathrm{t}}}=\frac{1}{\mathrm{k}_{2} \mathrm{q}_{\mathrm{e}}^{2}}+\frac{\mathrm{t}}{\mathrm{q}_{\mathrm{e}}}
$$

where $\mathrm{k}_{2}(\mathrm{~g} / \mathrm{mg} / \mathrm{min})$ is the pseudo-second-order rate constant. The slopes and intercepts of the plot of $t / q_{t}$ versus $t$ (Figure $6 b$ ) were used to calculate the $q_{e}\left(\mathrm{mg} / \mathrm{g}\right.$ ) and $k_{2}$ values [80]. The pseudo-second-order constant $k_{2}(\mathrm{~g} / \mathrm{mg} / \mathrm{min})$ and correlation coefficient $R^{2}$ values for the adsorption process of BB-3 on the $\mathrm{Pd}-\mathrm{Ni} / \mathrm{AC}$ were calculated and are listed in Table 2.

To understand the mechanism of the adsorption, an intraparticle diffusion model was used [76,77]:

$$
\mathrm{q}_{\mathrm{t}}=\mathrm{k}_{\mathrm{id}} \mathrm{t}_{\frac{1}{2}}+\mathrm{C}
$$

where $k_{i d}$ is the intraparticle diffusion constant, and C shows the thickness of boundary layer. The values are shown in Table 3. Figure $6 \mathrm{c}$ showed that the correlations do not pass through the origin, from which it can be concluded that the intraparticle and film diffusion are dominant.

The Elovich equation was applied to explain some aspects of the adsorption process. A mathematical form of the model can be expressed as [76,77]:

$$
\mathrm{q}_{\mathrm{t}}=\ln \frac{\beta \alpha}{\alpha}+\frac{\ln \mathrm{t}}{\beta}
$$

where $\alpha$ is the initial sorption rate $(\mathrm{mg} / \mathrm{g} / \mathrm{min})$, and the parameter $\beta$ is related to the extent of surface coverage and activation energy for chemisorption $(\mathrm{g} / \mathrm{mg})$ [81-83]. The $\mathrm{q}_{\mathrm{t}} \mathrm{vs}$. Int was plotted and is shown in Figure 6d, and the value of $\alpha$ and $\beta$ were determined, which are listed in Table 3.

The Natarajan and Khalaf equation gives the relationship between the initial dye concentration $\mathrm{C}_{0}$ and the concertation at a certain time $C_{t}$ [76,77]:

$$
\log \left(\frac{\mathrm{C}_{0}}{\mathrm{C}_{\mathrm{t}}}\right)=\frac{\mathrm{k}}{2.303} \mathrm{t}
$$

where $\mathrm{k}$ is the Khalaf constant, its value calculated by plotting $\log \left(\frac{\mathrm{C}_{0}}{\mathrm{C}_{\mathrm{t}}}\right)$ against time $\mathrm{t}$ (Figure 6e). The values of constants are given in Table 3.
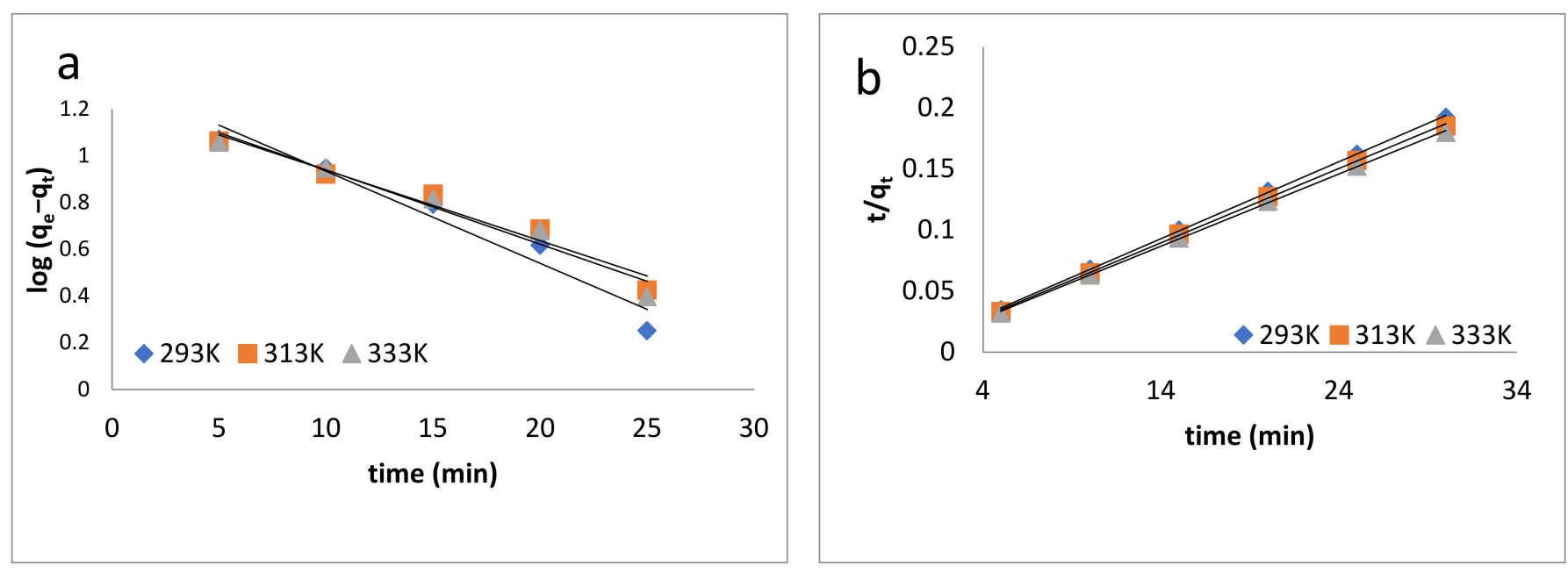

Figure 6. Cont. 

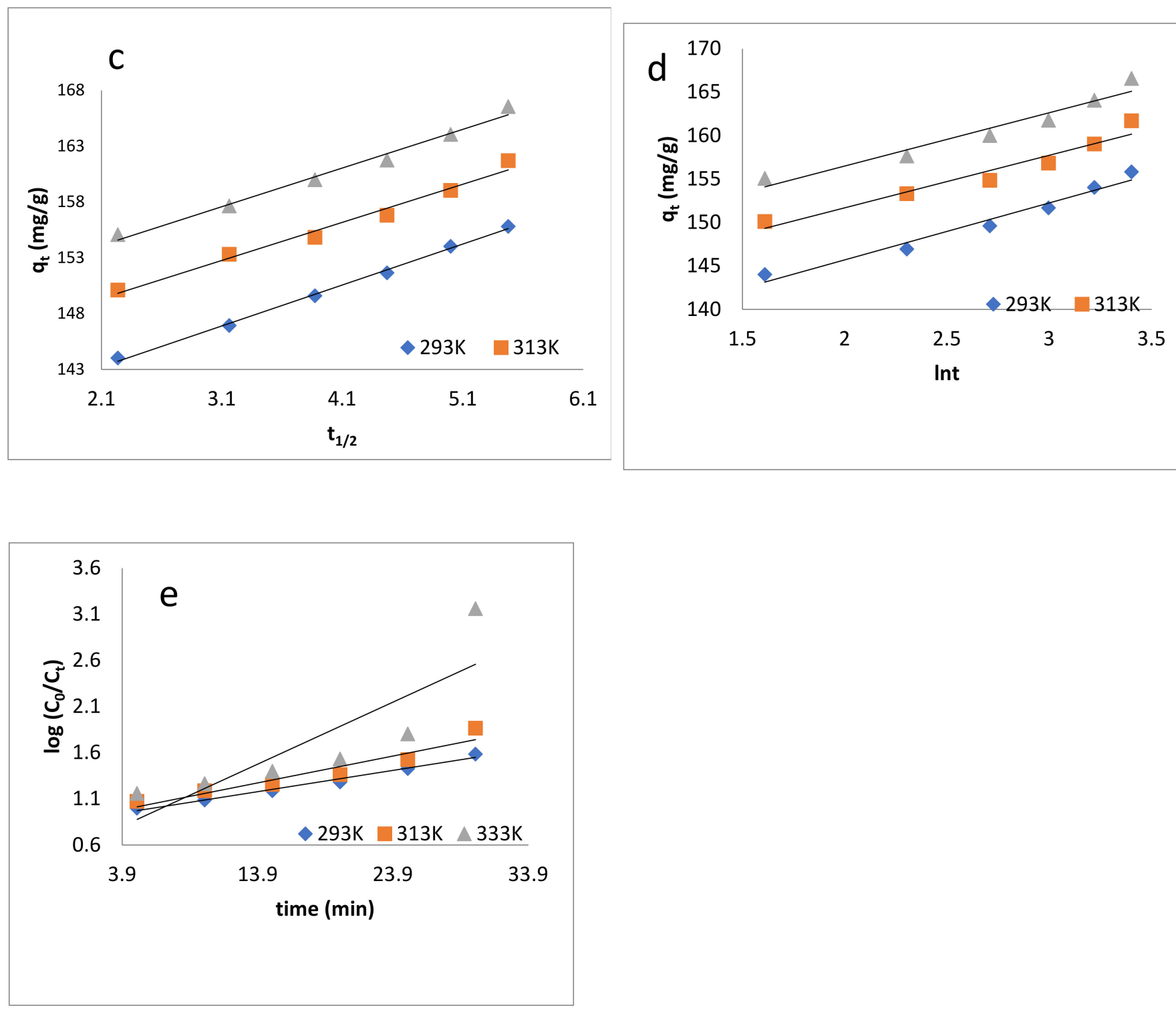

Figure 6. Kinetic models: (a) pseudo-first-order kinetics model; (b) pseudo-second-order kinetics model; (c) intraparticle diffusion model; (d) Elovich model; (e) Natarajan and Khalaf model.

Table 2. Temperature-dependent parameters of pseudo-first- and pseudo-second-order kinetics for adsorption of BB-3 on $\mathrm{Pd}-\mathrm{Ni} / \mathrm{AC}$.

\begin{tabular}{cccc}
\hline Parameter & $\mathbf{2 9 3} \mathbf{K}$ & $\mathbf{3 1 3} \mathbf{K}$ & 333 K \\
\hline \multicolumn{4}{c}{ Pseudo-first order } \\
\hline $\mathrm{q}_{\mathrm{e}}(\mathrm{cal})(\mathrm{mg} / \mathrm{g})$ & 21.281 & 17.414 & 17.782 \\
$\mathrm{q}_{\mathrm{e}}(\mathrm{exp})(\mathrm{mg} / \mathrm{g})$ & 155.825 & 161.705 & 166.55 \\
$\mathrm{k}_{1}\left(\mathrm{~min}^{-1}\right)$ & 0.091 & 0.069 & 0.073 \\
$\Delta \mathrm{q}^{\mathrm{N}}$ & 86.3 & 89.6 & 89.3 \\
$\mathrm{R}^{2}$ & 0.948 & 0.960 & 0.960 \\
\hline & Pseudo-second order & 169.49 \\
$\mathrm{q}_{\mathrm{e}}(\mathrm{cal})(\mathrm{mg} / \mathrm{g})$ & 158.73 & 163.93 & 166.551 \\
$\mathrm{q}_{\mathrm{e}}(\mathrm{exp})(\mathrm{mg} / \mathrm{g})$ & 155.825 & 161.705 & 0.0087 \\
$\mathrm{~K}_{2}(\mathrm{~g} / \mathrm{mg} / \mathrm{min})$ & 0.0086 & 0.0089 & 1.76 \\
$\Delta \mathrm{q} \%$ & 1.85 & 1.39 & 0.999 \\
$\mathrm{R}^{2}$ & 0.999 & 0.999 &
\end{tabular}


Table 3. Parameters of other kinetic models for adsorption of BB-3 on Pd-Ni/AC.

\begin{tabular}{|c|c|c|c|}
\hline Parameters & $293 \mathrm{~K}$ & $313 \mathrm{~K}$ & $333 \mathrm{~K}$ \\
\hline \multicolumn{4}{|c|}{ Intra-particle diffusion } \\
\hline $\mathrm{k}_{\mathrm{id}}\left(\mathrm{mg} / \mathrm{g} \min ^{-1 / 2}\right)$ & 3.6702 & 3.4089 & 3.4618 \\
\hline $\mathrm{C}$ & 135.53 & 142.21 & 146.87 \\
\hline $\mathrm{R}^{2}$ & 0.9972 & 0.9808 & 0.986 \\
\hline \multicolumn{4}{|c|}{ Elovich equation } \\
\hline$\alpha(\mathrm{mg} / \mathrm{g} \min )$ & $\alpha(\mathrm{mg} / \mathrm{g} \min )$ & $\alpha(\mathrm{mg} / \mathrm{g} \min )$ & $\alpha(\mathrm{mg} / \mathrm{g} \min )$ \\
\hline$\beta(\mathrm{mg} / \mathrm{g} \min )$ & $\beta(\mathrm{mg} / \mathrm{g} \min )$ & $\beta(\mathrm{mg} / \mathrm{g} \min )$ & $\beta(\mathrm{mg} / \mathrm{g} \min )$ \\
\hline $\mathrm{R}^{2}$ & $\mathrm{R}^{2}$ & $\mathrm{R}^{2}$ & $\mathrm{R}^{2}$ \\
\hline \multicolumn{4}{|c|}{ Natarajan and Khalaf equation } \\
\hline $\mathrm{k}\left(\min ^{-1}\right)$ & $\mathrm{k}\left(\min ^{-1}\right)$ & $\mathrm{k}\left(\min ^{-1}\right)$ & $\mathrm{k}\left(\min ^{-1}\right)$ \\
\hline $\mathrm{C}$ & C & $\mathrm{C}$ & $\mathrm{C}$ \\
\hline
\end{tabular}

\subsection{Isotherm Study}

In order to identify the superficial properties and affinity of the adsorbent for adsorbate, isotherm models were used. The isotherm study signified how the adsorbate interacted with the adsorbent and helped in enumerating adsorption capacities. Langmuir, Freundlich and Temkin models were applied to explain the experimental data [84].

\subsubsection{Langmuir Isotherm Model}

This model can be successfully applied to the adsorption of different organic and inorganic pollutants on various adsorbents. According to this model, the adsorption occurs in monolayers, and the process takes place at certain homogenous sites contained by the adsorbent $[76,77]$. The model can be expressed as

$$
\frac{C_{e}}{q_{e}}=\frac{C_{e}}{Q_{m}}+\frac{1}{K_{L} Q_{m}}
$$

where $C_{e}, q_{e}, K_{L}$ and $Q_{m}$ are the concentration of dye at equilibrium (mg/L), amount adsorbed at equilibrium $(\mathrm{mg} / \mathrm{g})$, Langmuir constant $(\mathrm{L} / \mathrm{g})$, and maximum adsorption capacity (mg/g), respectively [85]. Plotting $C_{e} / q_{e}$, versus $C_{e}$ enables us to determine the value of $K_{L}$ and $Q_{m}$ (from slope and intercept, Figure $7 a-c$ ). Their values, along with correlation coefficient $\mathrm{R}^{2}$, are given in Table 4 . The Langmuir maximum adsorption capacities for sorption of BB-3 on Pd-Ni/AC were found to be 238.95, 277.78 and $333.3 \mathrm{mg} / \mathrm{g}$ at 293,313 and $333 \mathrm{~K}$, respectively. Langmuir isotherm provided high correlation coefficient values and fit well with the experimental data.

\subsubsection{Freundlich Isotherm Model}

This model concerns non ideal and reversible adsorption processes, which are not limited to the formation of monolayer [76,77]. This model can be expressed as

$$
\ln \mathrm{q}_{\mathrm{e}}=\ln \mathrm{Kf}+\frac{1}{\mathrm{n}} \ln \mathrm{C}_{\mathrm{e}}
$$

where $\mathrm{C}_{\mathrm{e}}, \mathrm{q}_{\mathrm{e}}, \mathrm{Kf}$ and $1 / \mathrm{n}$ are the equilibrium dye concentrations, amount of dye adsorbed at equilibrium, adsorption capacity at unit concentration and adsorption intensity, respectively.

When $1 / \mathrm{n}=0$, the process will be irreversible; when $0<1 / \mathrm{n}<1$, the process will be favorable and when $1 / \mathrm{n}>1$, the process will be unfavorable [86]. 
A plot of $\operatorname{lnq}_{\mathrm{e}}$ versus $C_{\mathrm{e}}$ enables us to determine the values of the above parameters from the slope and intercept (Figure $7 \mathrm{~d}-\mathrm{f}$ ), the values of which are given in Table 4 . The values of $1 / \mathrm{n}$ were: $0.3181,0.3139$ and 0.3379 at 293,313 and $333 \mathrm{~K}$, respectively, which indicates that the adsorption process was energetically favorable.

\subsubsection{Temkin Isotherm Model}

This model has two basic assumptions: (i) with the coverage of the surface, the heat of adsorption increases due to a positive interaction between adsorbate and adsorbent, and (ii) adsorption is described as a homogeneous distribution of binding sites of uniform energies up to a certain limit $[76,77]$. This model can be expressed as

$$
\mathrm{q}_{\mathrm{e}}=\mathrm{B}_{1} \ln \mathrm{K}_{\mathrm{T}}+\mathrm{B}_{1} \ln \mathrm{C}_{\mathrm{e}}
$$

where $\mathrm{B}_{1}$ and $\mathrm{K}_{\mathrm{T}}$ are the heat of adsorption and the equilibrium binding constant $(\mathrm{L} / \mathrm{mg})$ respectively [87]. Plotting $\mathrm{q}_{\mathrm{e}}$ versus $\ln \mathrm{C}_{\mathrm{e}}$ enabled us to find out the values of these constants (Figure $7 \mathrm{~g}-\mathrm{i}$ ). Their values are given in Table 4.

According to Table 4 , the $\mathrm{R}^{2}$ values show that the adsorption of BB-3 Pd-Ni/AC isotherm followed the Langmuir isotherm, as its value was greater than that of the Freundlich and Temkin isotherms. This indicates that the present adsorption processes can be better described by the Langmuir than the Freundlich and Temkin models, suggesting that adsorption occurs as the monolayer on the homogenous adsorbent surface.
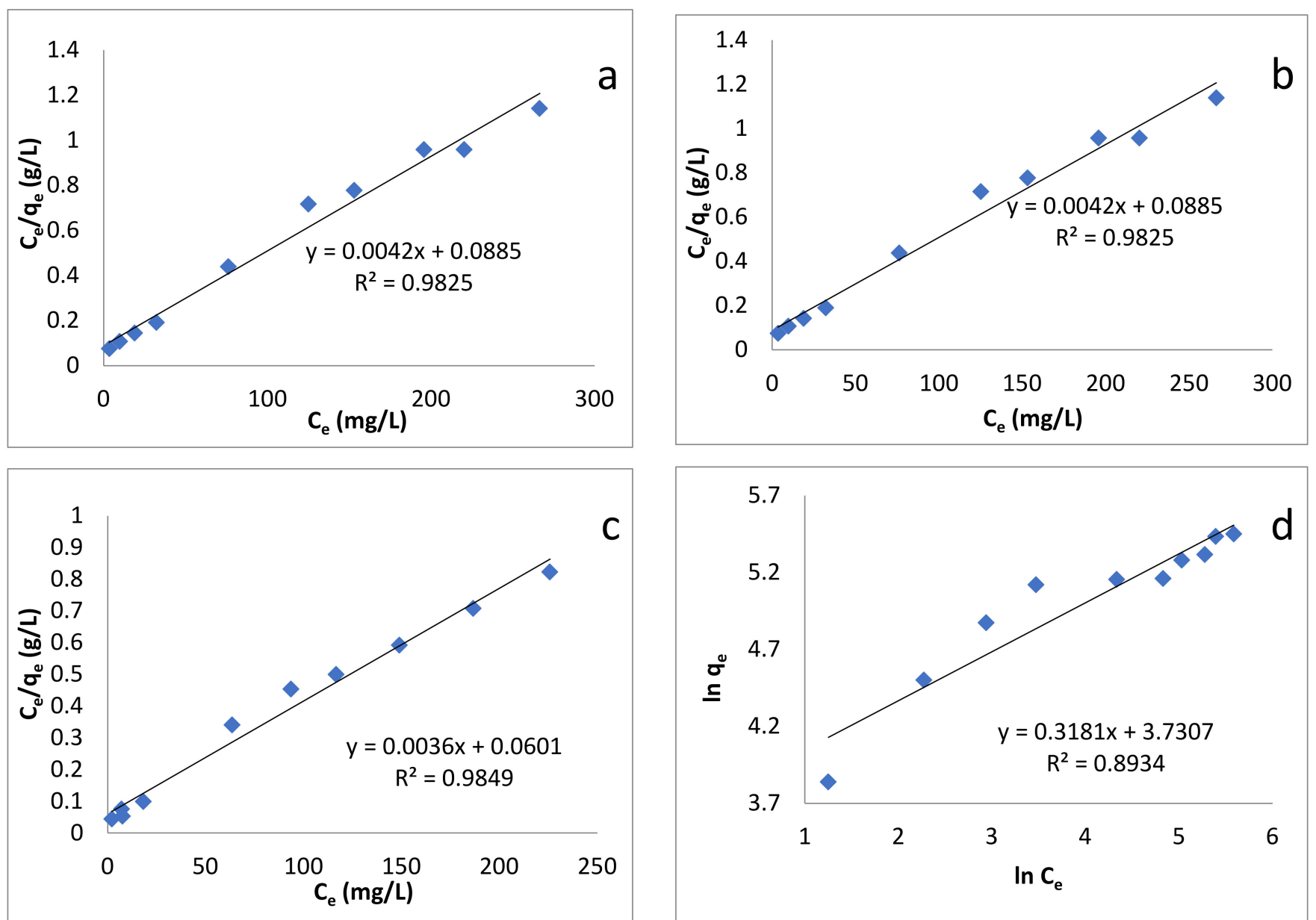

Figure 7. Cont. 

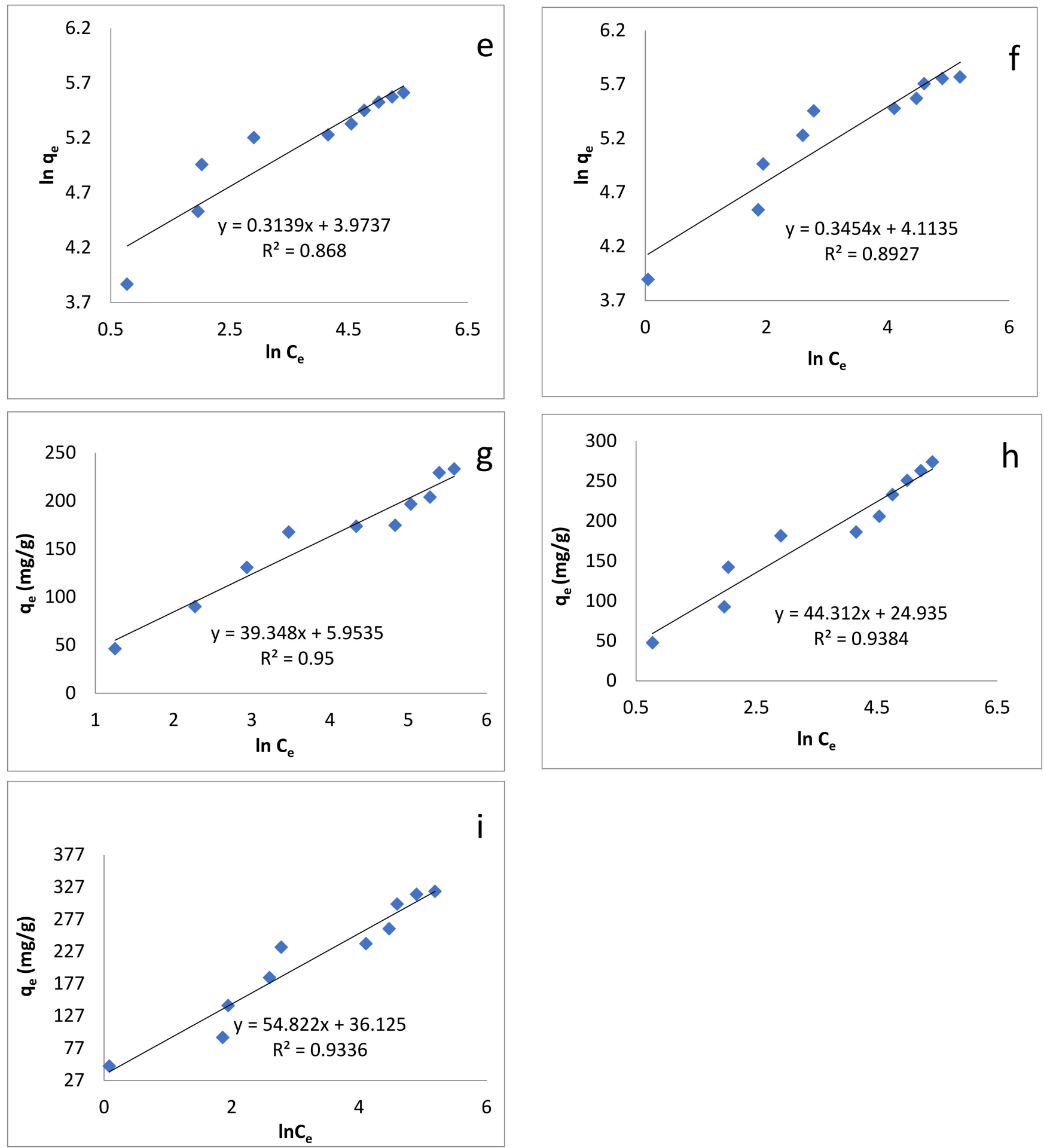

Figure 7. Adsorption isotherm models: (a) Langmuir isotherm at $293 \mathrm{~K}$; (b) Langmuir isotherm at $313 \mathrm{~K}$; (c) Langmuir isotherm at $333 \mathrm{~K}$; (d) Freundlich isotherm at $293 \mathrm{~K}$; (e) Freundlich isotherm at $313 \mathrm{~K}$; (f) Freundlich isotherm at $333 \mathrm{~K}$; (g) Temkin isotherm at $293 \mathrm{~K}$; (h) Temkin isotherm at $313 \mathrm{~K}$; (i) Temkin isotherm at $333 \mathrm{~K}$. 
Table 4. Parameters of isotherm study for adsorption of the BB-3 on Pd-Ni/AC.

\begin{tabular}{cccc}
\hline Parameter & $\mathbf{2 9 3} \mathbf{K}$ & $\mathbf{3 1 3} \mathbf{K}$ & $\mathbf{3 3 3} \mathbf{K}$ \\
\hline & \multicolumn{2}{c}{ Langmuir isotherm model } \\
\hline $\mathrm{Q}_{\mathrm{m}}(\mathrm{mg} / \mathrm{g})$ & 238.95 & 277.78 & 333.3 \\
$\mathrm{~K}_{\mathrm{a}}(\mathrm{g} / \mathrm{mg})$ & 0.00473 & 0.059 & 0.0824 \\
$\mathrm{R}^{2}$ & 0.9825 & 0.985 & 0.988 \\
$\mathrm{R}_{\mathrm{L}}$ & 0.297 & 0.032 & 0.023 \\
\hline & Freundlich isotherm model & \\
\hline $1 / \mathrm{n}$ & 0.3181 & 0.3139 & 0.3379 \\
$\mathrm{Kf}$ & 41.591 & 53.088 & 0.902 \\
$\mathrm{R}^{2}$ & 0.8934 & 0.868 & \\
\hline & Temkin isotherm model & 52.997 \\
$\mathrm{~B}_{1}$ & 39.348 & 44.312 & 2.264 \\
$\mathrm{~K}_{\mathrm{T}}$ & 1.163 & 1.717 & 0.9297 \\
$\mathrm{R}^{2}$ & 0.95 & 0.9384 & \\
\hline
\end{tabular}

\subsection{Thermodynamic Study}

The thermodynamic parameters attained for the adsorption of BB-3 onto Pd-Ni/AC were calculated using the following equations [76,77]:

$$
\Delta \mathrm{G}^{\circ}=-\mathrm{RT} \ln \mathrm{Ka}
$$

where $\mathrm{K}_{c}=\mathrm{Q}_{\mathrm{e}} / \mathrm{C}_{\mathrm{e}}$.

$$
\ln (\mathrm{Kc})=\frac{\Delta \mathrm{S}^{\circ}}{\mathrm{R}}-\frac{\Delta \mathrm{H}^{\circ}}{\mathrm{RT}}
$$

$\Delta \mathrm{G}^{\circ}, \Delta \mathrm{H}^{\circ}, \Delta \mathrm{S}^{\circ}, \mathrm{K}_{\mathrm{c}}$ and $\mathrm{K}_{\mathrm{a}}$ are the changes in Gibbs free energy, enthalpy, and entropy; the ratio of equilibrium adsorption; equilibrium concentration and the Langmuir constant, respectively. These values are given in Table 5, while the Van't Hoff plot is given in Figure 8.

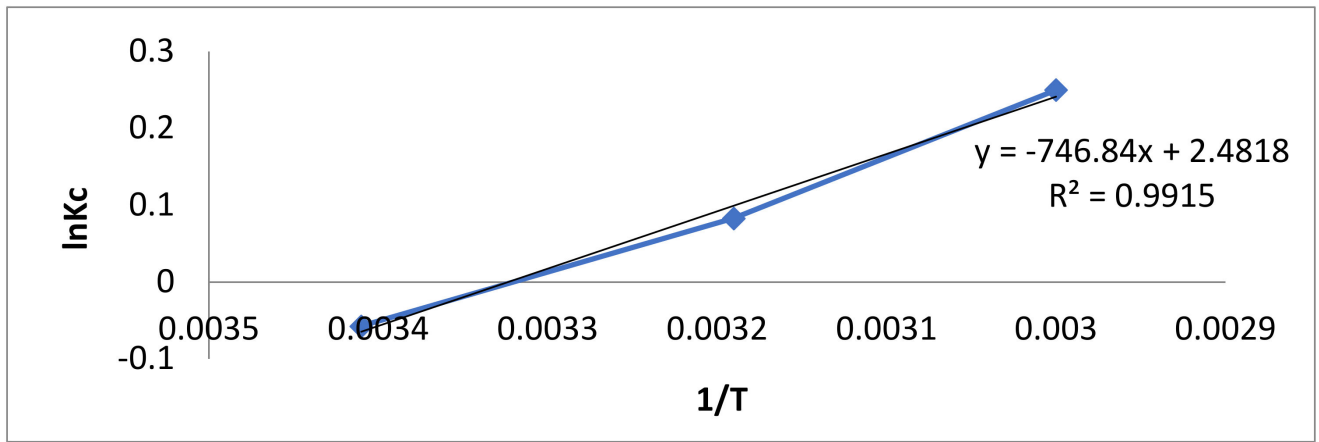

Figure 8. Van't Hoff plot of BB-3 adsorption on ternary composite.

At different temperatures, the Gibbs free energy change $\left(\Delta \mathrm{G}^{\circ}\right)$ was found to be negative, indicating that the adsorption process was feasible and spontaneous. The decline in $\Delta G^{\circ}$ values was found as temperature increased, indicating that the adsorption process occurs more favorably at lower temperatures [88]. The increased randomness at the dye/adsorbent interfaces and a strong affinity for the adsorption were verified by the positive value of change in enthalpy $\left(\Delta \mathrm{H}^{\circ}\right)$ [89]. During adsorption, a positive entropy change $\left(\Delta \mathrm{S}^{\circ}\right)$ indicated increased disorder at the solid-solution interface. 
Table 5. Thermodynamic parameters for adsorption of BB-3 on Pd-Ni/AC.

\begin{tabular}{ccccc}
\hline & $\Delta \mathbf{G}^{\circ}(\mathbf{k J} / \mathbf{m o l})$ & $\Delta \mathbf{H}^{\circ}(\mathbf{k J} / \mathbf{m o l})$ & $\Delta \mathbf{S}^{\circ}(\mathbf{k J} / \mathbf{m o l ~ K})$ \\
\hline $293 \mathrm{~K}$ & $313 \mathrm{~K}$ & $333 \mathrm{~K}$ & -6.206 & 0.0242 \\
-13.297 & -13.780 & -14.264 & & \\
\hline
\end{tabular}

\subsection{Regeneration Study}

To determine the regeneration efficiency of $\mathrm{Pd}-\mathrm{Ni} / \mathrm{AC}$, the sample was washed with suitable eluents (dilute sodium hydroxide and ethanol) and then used several times, and the removal efficiency was monitored. From Figure 9 it was found that the removal efficiency was reduced up to $79 \%$ after six rounds of regeneration, showing that $\mathrm{Pd}-\mathrm{Ni} / \mathrm{AC}$ can be used with a sufficient efficiency up to several cycles.

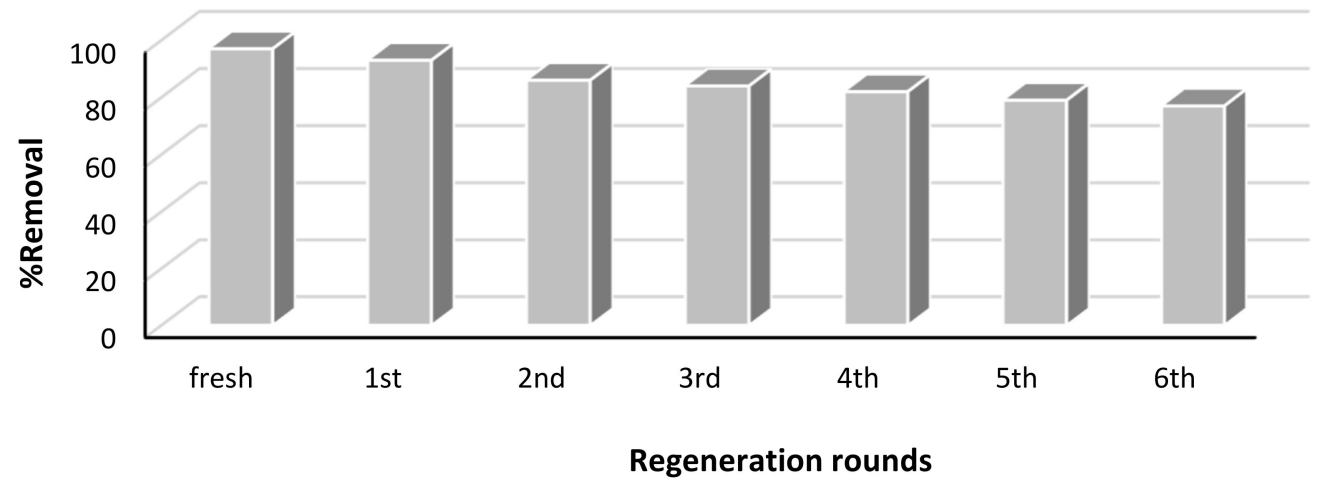

Figure 9. Regeneration of adsorbents $\mathrm{Pd}-\mathrm{Ni} / \mathrm{AC}$ on dye treatment.

\subsection{Comparing Adsorption Capacities of Reported Adsorbents with Current Adsorbent}

$\mathrm{Pd}-\mathrm{Ni}$ nanoparticles as an adsorbent showed maximum adsorption capacity compared with previously reported results [90-94] (Table 6). Hence, Pd-Ni nanoparticles may be an effective adsorbent for the removal of BB-3 dye and other pollutants. Previous studies have shown the assessment of the effects of $\mathrm{pH}$ and other factors on the solubility and performance of nanomaterials, which could be applied similarly in future studies [95-97].

Table 6. Comparison of adsorption capacities of various adsorbents for the removal of BB-3 within our current study.

\begin{tabular}{cccc}
\hline Adsorbent & Pollutant & $\mathbf{Q}_{\max }(\mathbf{m g} / \mathbf{g})$ & References \\
\hline Ternary polymer composites & BB-3 & 200 & {$[90]$} \\
Chitosan-based adsorbent & BB-3 & 134.5 & {$[91]$} \\
Sulfuric Acid-Activated & BB-3 & 277 & {$[92]$} \\
Montmorillonite Mineral & & 49.50 & {$[93]$} \\
durian peel (Durio zibethinus Murray) & BB-3 & 59.53 & {$[94]$} \\
Weak acid acrylic resin & BB-3 & 333 & Current study \\
Pd-Ni nanoparticles & BB-3 & & \\
\hline
\end{tabular}

\section{Conclusions}

The aim of this study was to synthesize the $\mathrm{Pd}-\mathrm{Ni}$ nanomaterials and to impregnate them onto activated carbon to enhance the surface of prepared nanoparticles. The prepared ternary adsorbent was used as an efficient adsorbent for the removal of basic blue 3 (BB-3) from water. The bifunctional alloy formation was confirmed from the metal analyses by XRD and the surface morphology by SEM analysis. About $94 \%$ removal of the BB-3 was achieved through the prepared adsorbent, indicating its high efficiency to remove the selected dye from water. Various equilibrium and kinetics models were used to calculate 
different parameters of the adsorption, where pseudo-second-order kinetics and Langmuir models were found to be the best models that accommodated the experimental data with high $\mathrm{R}^{2}$ values. The calculated thermodynamic parameters showed the process to be spontaneous $\left(\Delta \mathrm{S}^{\circ}=0.0242 \mathrm{~kJ} / \mathrm{mol} \mathrm{K}\right.$ and $\Delta \mathrm{G}^{\circ}=-13.297,-13.780$ and $-14.264 \mathrm{~kJ} / \mathrm{mol}$, respectively at 293,313 and $333 \mathrm{~K})$ and exothermic $\left(\Delta \mathrm{H}^{\circ}=-6.206 \mathrm{~kJ} / \mathrm{mol}\right)$ in nature. The prepared adsorbent was effective in the removal of the selected dye and further tests are needed to evaluate its applicability for other pollutants as well.

Author Contributions: Conceptualization, M.Z.; methodology, A.U.; software, A.U.; validation, S.S.d.R., A.U. and I.Z.; formal analysis, A.U. and J.B.; investigation, A.U. and A.K. (Abbas Khan); resources, M.Z.; data curation, S.A.; writing-original draft preparation, I.Z.; writing-review and editing, M.S.K. and G.D.B.; visualization, R.K., M.S.K. and N.u.R.; supervision, M.Z.; project administration, M.Z., A.K. (Anna Kallistova), N.P. and M.M.G.; funding acquisition, M.Z. All authors have read and agreed to the published version of the manuscript.

Funding: This research was funded by project number T190087MIMV and the European Commission, MLTKT19481R “Identifying best available technologies for decentralized wastewater treatment and resource recovery for India" and SLTKT20427 "Sewage sludge treatment from heavy metals, emerging pollutants and recovery of metals by fungi", and by projects KIK 15392 and 15401 by the European Commission.

Institutional Review Board Statement: Not applicable.

Informed Consent Statement: Not applicable.

Conflicts of Interest: The authors declare no conflict of interest. The funders had no role in the design of the study; in the collection, analyses or interpretation of data; in the writing of the manuscript or in the decision to publish the results.

\section{References}

1. Anastopoulos, A.; Hosseini-Bandegharaei, A.; Fu, J.; Mitropoulos, A.C.; Kyzas, G.Z. Use of Nanoparticles for Dye Adsorption. J. Dispers. Sci. Technol. 2018, 39, 836-847. [CrossRef]

2. Marimuthu, A.J.; Antonisamy, S.; Malayandi, K.; Rajendran, P.-C.; Tsai, A.; Pugazhendhi, V.K.; Ponnusamy, S. Silver Nanoparticles in Dye Effluent Treatment: A Review on Synthesis, Treatment Methods, Mechanisms, Photocatalytic Degradation, Toxic Effects and Mitigation of Toxicity. J. Photochem. Photobiol. B Biol. 2020, 205, 111823. [CrossRef] [PubMed]

3. Zeitoun, M.M.; Mehana, E. Impact of Water Pollution with Heavy Metals on Fish Health: Overview and Updates. Glob. Vet. 2014, 12, 219-231.

4. $\quad$ Feng, P.; Zhang, H.-C.; Zhou, V.K.; Sharma, M. Water-Stable Metal-Organic Frameworks for Aqueous Removal of Heavy Metals and Radionuclides: A Review. Chemosphere 2018, 209, 783-800. [CrossRef]

5. Eisenhauer, H.R. Oxidation of Phenolic Wastes. J. Water Pollut. Control Fed. 1964, 36, 1116-1128.

6. Anju, A.P.; Ravi, S.; Bechan, S. Water Pollution with Special Reference to Pesticide Contamination in India. J. Water Resour. Prot. 2010, 2010. [CrossRef]

7. Martínez, E.R.G.; Gonzalo, M.E.F.; Laespada, F.J.S.; San Roman, R.C. Evaluation of Surface-and Ground-Water Pollution due to Herbicides in Agricultural Areas of Zamora and Salamanca (Spain). J. Chromatogr. A 2000, 869, 471-480. [CrossRef]

8. Cheng, D.; Ngo, H.H.; Guo, W.; Chang, S.W.; Nguyen, D.D.; Liu, Y.; Wei, Q.; Wei, D. A Critical Review on Antibiotics and Hormones in Swine Wastewater: Water Pollution Problems and Control Approaches. J. Hazard. Mater. 2020, $387,121682$. [CrossRef]

9. Padhi, B. Pollution due to Synthetic Dyes Toxicity \& Carcinogenicity Studies and Remediation. Int. J. Environ. Sci. 2012, 3, 940.

10. Rehman, M.; Usman, T.H.; Bokhari, A.; Ul Haq, M.; Saeed, H.M.A.U.; Rahman, M.; Siddiq, A.; Rasheed, M.U.; Nisa, A. The Application of Cationic-Nonionic Mixed Micellar Media for Enhanced Solubilization of Direct Brown 2 Dye. J. Mol. Liq. 2020, 301, 112408. [CrossRef]

11. Ikram, M.; Zahoor, M.; Gaber El-Saber, B. Biodegradation and decolorization of textile dyes by bacterial strains: A biological approach for wastewater treatment. Z. Phys. Chem. 2020. [CrossRef]

12. Gupta, V.K.; Kumar, R.; Nayak, A.; Saleh, T.A.; Barakat, M.A. Adsorptive Removal of Dyes from Aqueous Solution onto Carbon Nanotubes: A Review. Adv. Colloid Interface Sci. 2013, 193-194, 24-34. [CrossRef]

13. Tara, S.I.; Siddiqui, G.; Rathi, S.A.; Chaudhry, A.M.; Asiri, N. Nano-Engineered Adsorbent for the Removal of Dyes from Water: A Review. Curr. Anal. Chem. 2020, 16, 14-40. [CrossRef]

14. Routoula, S.V.; Patwardhan, E. Degradation of Anthraquinone Dyes from Effluents: A Review Focusing on Enzymatic Dye Degradation with Industrial Potential. Environ. Sci. Technol. 2020, 54, 647-664. [CrossRef] 
15. Allen, S.; Mckay, G.; Porter, J.F. Adsorption Isotherm Models for Basic Dye Adsorption by Peat in Single and Binary Component Systems. J. Colloid Interface Sci. 2004, 280, 322-333. [CrossRef]

16. Arıca, M.Y.; Bayramoğlu, G. Biosorption of Reactive Red-120 dye from Aqueous Solution by Native and Modified Fungus Biomass Preparations of Lentinus Sajor-caju. J. Hazard. Mater. 2007, 149, 499-507. [CrossRef]

17. Osugi, M.E.; Umbuzeiro, G.A.; De Castro, F.J.; Zanoni, M.V.B. Photoelectrocatalytic Oxidation of Remazol Turquoise Blue and Toxicological Assessment of its Oxidation Products. J. Hazard. Mater. 2006, 137, 871-877. [CrossRef]

18. Bafana, A.; Jain, M.; Agrawal, G.; Chakrabarti, T. Bacterial Reduction in Genotoxicity of Direct Red 28 Dye. Chemosphere 2009, 74, 1404-1406. [CrossRef]

19. Wong, P.; Yuen, P. Decolorization and Biodegradation of Methyl Red by Klebsiella Pneumoniae RS-13. Water Res. 1996, 30, 1736-1744. [CrossRef]

20. Fiedurek, J.; Gromada, A. Production of Catalase and Glucose Oxidase by Aspergillus Niger using Unconventional Oxygenation of Culture. J. Appl. Microbial. 2000, 89, 85-89. [CrossRef]

21. Nigam, P.; Armour, G.; Banat, I.; Singh, D.; Marchant, R. Physical Removal of Textile Dyes from Effluents and Solid-State Fermentation of Dye-Adsorbed Agricultural Residues. Bioresour. Technol. 2000, 72, 219-226. [CrossRef]

22. Bayramoğlu, G.; Arıca, M.Y. Biosorption of Benzidine based Textile Dyes. Direct Blue 1 and Direct Red 128" using Native and Heat-Treated Biomass of Trametes Versicolor. J. Hazard. Mater. 2007, 143, 135-143. [CrossRef]

23. Gadd, G.M. Metals and Microorganisms: A Problem of Definition. FEMS Microbiol. Lett. 1992, 100, 197-203. [CrossRef]

24. Binupriya, A.; Sathishkumar, M.; Swaminathan, K.; Kuz, C.; Yun, S. Comparative Studies on Removal of Congo Red by Native and Modified Mycelial Pellets of Trametes Versicolor in Various Reactor Modes. Bioresour. Technol. 2008, 99, 1080-1088. [CrossRef] [PubMed]

25. Nigam, P.S.N.; Banat, I.; Oxspring, D.; Marchant, R.; Singh, D.; Smyth, W. A New Facultative Anaerobic Filamentous Fungus Capable of Growth on Recalcitrant Textile Dyes as Sole Carbon Source. Microbios 1995, 84, 171-185.

26. Ponraj, M.; Gokila, K.; Zambare, V. Bacterial Decolorization of Textile Dye-Orange 3R. Int. J. Adv. Biotechnol. Res. 2011, 2, 168-177.

27. Tapia-Tussell, R.; Pereira-Patrón, A.; Alzate-Gaviria, L.; Lizama-Uc, G.; Pérez-Brito, D.; Solis-Pereira, S. Decolorization of Textile Effluent by Trametes Hirsuta Bm-2 and lac-T as Possible Main Laccase-Contributing Gene. Curr. Microbiol. 2020, 77, $3953-3961$. [CrossRef]

28. Ekanayake, M.S.; Udayanga, D.; Wijesekara, I.; Manage, P. Phytoremediation of Synthetic Textile Dyes: Biosorption and Enzymatic Degradation Involved in Efficient Dye Decolorization by Eichhornia Crassipes (Mart.) Solms and Pistia Stratiotes L. Environ. Sci. Pollut. Res. 2021, 1-11. [CrossRef]

29. Dellamatrice, P.M.; Silva-Stenico, M.E.; Moraes, L.A.B.D.; Fiore, M.F.; Monteiro, T.R. Degradation of Textile Dyes by Cyanobacteria. Braz. J. Microbial. 2017, 48, 25-31. [CrossRef]

30. Lopez-Barbosa, N.; Florez, S.L.; Cruz, J.C.; Ornelas-Soto, N.; Osma, J.F. Congo Red Decolorization Using Textile Filters and Laccase-Based Nanocomposites in Continuous Flow Bioreactors. Nanomaterials 2020, 10, 1227. [CrossRef]

31. Nagajyothi, P.; Prabhakar Vattikuti, S.; Devarayapalli, K.; Yoo, K.; Shim, J.; Sreekanth, T. Green Synthesis: Photocatalytic Degradation of Textile Dyes using Metal and Metal Oxide Nanoparticles-Latest Trends and Advancements. Crit. Rev. Environ. Sci. Technol. 2020, 50, 2617-2723. [CrossRef]

32. Bilińska, L.; Blus, K.; Foszpańczyk, M.; Gmurek, M.; Ledakowicz, S. Catalytic Ozonation of Textile Wastewater as a Polishing Step after Industrial Scale Electrocoagulation. J. Environ. Manag. 2020, 265, 110502. [CrossRef] [PubMed]

33. Han, Y.; Li, H.; Liu, M.; Sang, Y.; Liang, C.; Chen, J. Purification Treatment of Dyes Wastewater with a Novel Micro-Electrolysis Reactor. Sep. Purif. Technol. 2016, 170, 241-247. [CrossRef]

34. Wawrzkiewicz, M.; Hubicki, Z. Anion Exchange Resins as Effective Sorbents for Removal of Acid, Reactive, and Direct Dyes from Textile Wastewaters. Ion Exch. Stud. Appl. 2015, 37-72. [CrossRef]

35. Alderete, B.L.; da Silva, J.; Godoi, R.; da Silva, F.R.; Taffarel, S.R.; da Silva, L.P.; Garcia, A.L.H.; Júnior, H.M.; de Amorim, H.L.N.; Picada, J.N. Evaluation of Toxicity and Mutagenicity of a Synthetic Effluent Containing Azo Dye after Advanced Oxidation Process Treatment. Chemosphere 2020, 263, 128291. [CrossRef]

36. Long, Q.; Zhang, Z.; Qi, G.; Wang, Z.; Chen, Y.; Liu, Z.-Q. Fabrication of Chitosan Nanofiltration Membranes by the Film Casting Strategy for Effective Removal of Dyes/Salts in Textile Wastewater. ACS Sustain. Chem. Eng. 2020, 8, 2512-2522. [CrossRef]

37. Demissie, H.; An, G.; Jiao, R.; Ritigala, T.; Lu, S.; Wang, D. Modification of High Content Nanocluster-Based Coagulation for Rapid Removal of Dye from Water and the Mechanism. Sep. Purif. Technol. 2021, 259, 117845. [CrossRef]

38. Wang, K.; Wei, T.; Li, Y.; He, L.; Lv, Y.; Chen, L.; Ahmad, A.; Xu, Y.; Shi, Y. Flocculation-to-Adsorption Transition of Novel Salt-Responsive Polyelectrolyte for Recycling of Highly Polluted Saline Textile Effluents. Chem. Eng. J. 2021, $413,127410$. [CrossRef]

39. Pakhale, V.D.; Gogate, P.R. Removal of Rhodamine 6G from Industrial Wastewater Using Combination Approach of Adsorption Followed by Sonication. Arab. J. Sci. Eng. 2021, 1-12. [CrossRef]

40. Aljeboree, A.M.; Al-Gubury, H.Y.; Bader, A.T.; Alkaim, A.F. Adsorption of Textile Dyes in the Presence Either Clay or Activated Carbon as a Technological Models: A Review. J. Crit. Rev. 2020, 7, 620-626.

41. Deniz, F. Adsorption Properties of Low-Cost Biomaterial Derived from Prunus Amygdalus L. for Dye Removal from Water. Sci. World J. 2013, 2013. [CrossRef] 
42. Rafatullah, M.; Sulaiman, O.; Hashim, R.; Ahmad, A. Adsorption of Methylene Blue on Low-Cost Adsorbents: A Review. J. Hazard. Mater. 2010, 177, 70-80. [CrossRef]

43. Dabrowski, A. Adsorption-From Theory to Practice. Adv. Colloid Interface Sci. 2001, 93, 135-224. [CrossRef]

44. Allen, S.; Koumanova, B. Decolourisation of Water/Wastewater using Adsorption. J. Univ. Chem. Technol. Metall. 2005, 40, 175-192.

45. Adak, A.; Bandyopadhyay, M.; Pal, A. Adsorption of Anionic Surfactant on Alumina and Reuse of the Surfactant-Modified Alumina for the Removal of Crystal Violet from Aquatic Environment. J. Environ. Sci. Health 2005, 40, 167-182. [CrossRef]

46. Kausar, A.; Iqbal, M.; Javed, A.; Aftab, K.; Bhatti, H.N.; Nouren, S. Dyes Adsorption using Clay and Modified Clay: A Review. J. Mol. Liq. 2018, 256, 395-407. [CrossRef]

47. Kumar, P.S.; Joshiba, G.J.; Femina, C.C.; Varshini, P.; Priyadharshini, S.; Karthick, M.A.; Jothirani, R. A Critical Review on Recent Developments in the Low-Cost Adsorption of Dyes from Wastewater. Desalin. Water Treat. 2019, 172, 395-416. [CrossRef]

48. Mouni, L.; Belkhiri, L.; Bollinger, J.-C.; Bouzaza, A.; Assadi, A.; Tirri, A.; Dahmoune, F.; Madani, K.; Remini, H. Removal of Methylene Blue from Aqueous Solutions by Adsorption on Kaolin: Kinetic and Equilibrium Studies. Appl. Clay Sci. 2018, 153, 38-45. [CrossRef]

49. Huang, Z.; Li, Y.; Chen, W.; Shi, J.; Zhang, N.; Wang, X.; Li, Z.; Gao, L.; Zhang, Y. Modified Bentonite Adsorption of Organic Pollutants of Dye Wastewater. Mater. Chem. Phys. 2017, 202, 266-276. [CrossRef]

50. Astuti, W.; Sulistyaningsih, T.; Maksiola, M. Equilibrium and Kinetics of Adsorption of Methyl Violet from Aqueous Solutions Using Modified Ceiba Pentandra Sawdust. Asian J. Chem. 2017, 29, 133-138. [CrossRef]

51. Alouani, M.; Alehyen, S.; Achouri, M.; Taibi, M. Removal of Cationic Dye-Methylene Blue-From Aqueous Solution by Adsorption on Fly Ash-Based Geopolymer. J. Mater. Environ. Sci. 2018, 9, 32-46.

52. Brião, G.V.; Jahn, S.L.; Foletto, E.L.; Dotto, G.L. Highly Efficient and Reusable Mesoporous Zeolite Synthetized from a Biopolymer for Cationic Dyes Adsorption. Colloids Surf. A Physicochem. Eng. Asp. 2018, 556, 43-50. [CrossRef]

53. Yao, S.; Xu, T.; Zhao, N.; Zhang, L.; Huo, Q.; Liu, Y. An Anionic Metal-Organic Framework with Ternary Building Units for Rapid and Selective Adsorption of Dyes. Dalton Trans. 2017, 46, 3332-3337. [CrossRef] [PubMed]

54. Nakhjiri, M.T.; Marandi, G.B.; Kurdtabar, M. Poly (AA-co-VPA) Hydrogel Cross-Linked with N-Maleyl Chitosan as Dye Adsorbent: Isotherms, Kinetics and Thermodynamic Investigation. Int. J. Biol. Macromol. 2018, 117, 152-166. [CrossRef]

55. Kyzas, G.Z.; Bikiaris, D.N.; Lazaridis, N.K. Selective Separation of Basic and Reactive Dyes by Molecularly Imprinted Polymers (MIPs). Chem. Eng. J. 2009, 149, 263-272. [CrossRef]

56. Deb, A.; Kanmani, M.; Debnath, A.; Bhowmik, K.L.; Saha, B. Ultrasonic Assisted Enhanced Adsorption of Methyl Orange Dye onto Polyaniline Impregnated Zinc Oxide Nanoparticles: Kinetic, Isotherm and Optimization of Process Parameters. Ultrason. Sonochem. 2019, 54, 290-301. [CrossRef]

57. Gu, J.; Hu, C.; Zhang, W.; Dichiara, A.B. Reagentless Preparation of Shape Memory Cellulose Nanofibril Aerogels Decorated with Pd Nanoparticles and their Application in Dye Discoloration. Appl. Catal. B Environ. 2018, 237, 482-490. [CrossRef]

58. Mirzajani, R.; Karimi, S. Ultrasonic Assisted Synthesis of Magnetic Ni-Ag Bimetallic Nanoparticles Supported on Reduced Graphene Oxide for Sonochemical Simultaneous Removal of Sunset Yellow and Tartrazine Dyes by Response Surface Optimization: Application of Derivative Spectrophotometry. Ultrason. Sonochem. 2019, 50, 239-250.

59. Hasan, S. A Review on Nanoparticles: Their Synthesis and Types. Res. J. Recent Sci. 2015, 2277, 2502.

60. Wiechers, J.W.; Musee, N. Engineered Inorganic Nanoparticles and Cosmetics: Facts, Issues, Knowledge Gaps and Challenges. J. Biomed. Nanotechnol. 2010, 6, 408-431. [CrossRef]

61. Teng, W.-Y.; Jeng, S.-C.; Kuo, C.-W.; Lin, Y.-R.; Liao, C.-C.; Chin, W.-K. Nanoparticles-Doped Guest-Host Liquid Crystal Displays. Opt. Lett. 2008, 33, 1663-1665. [CrossRef]

62. Li, Y.; Hong, X.M.; Collard, D.M.; El-Sayed, M.A. Suzuki Cross-Coupling Reactions Catalyzed by Palladium Nanoparticles in Aqueous Solution. Organ. Lett. 2000, 2, 2385-2388. [CrossRef]

63. Chavanpatil, M.D.; Khdair, A.; Panyam, J. Surfactant-Polymer Nanoparticles: A Novel Platform for Sustained and Enhanced Cellular Delivery of Water-Soluble Molecules. Pharm. Res. 2007, 24, 803-810. [CrossRef]

64. Roy, I.; Ohulchanskyy, T.Y.; Pudavar, H.E.; Bergey, E.J.; Oseroff, A.R.; Morgan, J.; Dougherty, T.J.; Prasad, P.N. Ceramic-based Nanoparticles Entrapping Water-Insoluble Photosensitizing Anticancer Drugs: A NOVEL drug-Carrier System for Photodynamic Therapy. J. Am. Chem. Soc. 2003, 125, 7860-7865. [CrossRef]

65. Jia, Q.; Nguyen, P.K.; Gu, Z.; Zhang, X.; Liu, M.; Tian, X.; Ma, L.; Gong, L.; Mu, X.; Chang, Y. N-Doped Bismuth Molybdate Decorated with Pt Nanoparticles Removal Azo Dyes Efficiently via the Synergistic Effect of Adsorption and Photocatalysis. J. Alloys Compd. 2021, 863, 158336. [CrossRef]

66. Lim, I.I.S.; Goroleski, F.; Mott, D.; Kariuki, N.; Ip, W.; Luo, J.; Zhong, C.-J. Adsorption of Cyanine Dyes on Gold Nanoparticles and Formation of J-Aggregates in the Nanoparticle Assembly. J. Phys. Chem. B 2006, 110, 6673-6682. [CrossRef]

67. Asfaram, A.; Ghaedi, M.; Agarwal, S.; Tyagi, I.; Gupta, V.K. Removal of Basic Dye Auramine-O by ZnS: Cu Nanoparticles Loaded on Activated Carbon: Optimization of Parameters using Response Surface Methodology with Central Composite Design. RSC Adv. 2015, 5, 18438-18450. [CrossRef]

68. Bokare, A.D.; Chikate, R.C.; Rode, C.V.; Paknikar, K.M. Iron-Nickel Bimetallic Nanoparticles for Reductive Degradation of Azo Dye Orange G in Aqueous Solution. Appl. Catal. B Environ. 2008, 79, 270-278. [CrossRef] 
69. Ismail, M.; Khan, M.; Khan, S.B.; Khan, M.A.; Akhtar, K.; Asiri, A.M. Green Synthesis of Plant Supported CuAg and CuNi Bimetallic Nanoparticles in the Reduction of Nitrophenols and Organic Dyes for Water Treatment. J. Mol. Liq. 2018, 260, 78-91. [CrossRef]

70. Gautam, R.K.; Rawat, V.; Banerjee, S.; Sanroman, M.A.; Soni, S.; Singh, S.K.; Chattopadhyaya, M.C. Synthesis of Bimetallic Fe-Zn Nanoparticles and its Application towards Adsorptive Removal of Carcinogenic Dye Malachite Green and Congo Red in Water. J. Mol. Liq. 2015, 212, 227-236. [CrossRef]

71. Kaewmanee, T.; Phuruangrat, A.; Thongtem, T.; Thongtem, S. Solvothermal Synthesis of $\mathrm{Mn}-\mathrm{Zn}$ Ferrite (core)@ SiO 2 (shell) $/ \mathrm{BiOBr}_{0.5} \mathrm{Cl}_{0.5}$ Nanocomposites used for Adsorption and Photocatalysis Combination. Ceram. Int. 2020, 46, 3655-3662. [CrossRef]

72. Xu, J.; Liu, X.; Lowry, G.V.; Cao, Z.; Zhao, H.; Zhou, J.L.; Xu, X. Dechlorination Mechanism of 2, 4-Dichlorophenol by Magnetic MWCNTs Supported Pd/Fe Nanohybrids: Rapid Adsorption, Gradual Dechlorination, and Desorption of Phenol. ACS Appl. Mater. Interfaces 2016, 8, 7333-7342. [CrossRef] [PubMed]

73. Sharma, G.; Gupta, V.K.; Agarwal, S.; Kumar, A.; Thakur, S.; Pathania, D. Fabrication and Characterization of Fe@ MoPO Nanoparticles: Ion Exchange Behavior and Photocatalytic Activity against Malachite Green. J. Mol. Liq. 2016, 219, 1137-1143. [CrossRef]

74. Sharma, G.; Kumar, A.; Sharma, S.; Naushad, M.; Dwivedi, R.P.; ALOthman, Z.A.; Mola, G.T. Novel Development of Nanoparticles to Bimetallic Nanoparticles and Their Composites: A Review. J. King Saud Univ. Sci. 2019, 31, 257-269. [CrossRef]

75. Alvarenga, G.M.; Gallo, I.B.C.; Villullas, H.M. Enhancement of Ethanol Oxidation on Pd Nanoparticles Supported on CarbonAntimony tin Oxide Hybrids Unveils the Relevance of Electronic Effects. J. Catal. 2017, 348, 1-8. [CrossRef]

76. Shamim, A.; Begum, A.H.M.; Hyder, G.; Vahdat, N. Adsorption Isotherm and Kinetic Studies of As(V) Removal from Aqueous Solution Using Cattle Bone Char. J. Water Supply Res. Technol. AQUA 2016, 65, 244-252.

77. Hyder, M.G.; Shamim, A.B.; Nosa, O.; Egiebor, A.H. Sorption Studies of Cr(VI) from Aqueous Solution using Biochar as an Adsorbent. Water Sci. Technol. 2014, 69, 2265-2271. [CrossRef]

78. Ghaedi, A.M.; Ansari, M.H.; Asghari, A. Removal of Malachite Green from Aqueous Solution by Zinc Oxide Nanoparticle Loaded on Activated Carbon: Kinetics and Isotherm Study. J. Ind. Eng. Chem. 2014, 20, 17-28. [CrossRef]

79. Ghaedi, M.; Ansari, A.; Sahraei, R. ZnS: Cu Nanoparticles Loaded on Activated Carbon as Novel Adsorbent for Kinetic, Thermodynamic and Isotherm Studies of Reactive Orange 12 and Direct Yellow 12 Adsorption. Spectrochim. Acta Part A Mol. Biomol. Spectrosc. 2013, 114, 687-694. [CrossRef]

80. Asfaram, A.; Ghaedi, M.; Hajati, S.; Rezaeinejad, M.; Goudarzi, A.; Purkait, M.K. Rapid Removal of Auramine-O and Methylene Blue by ZnS: Cu Nanoparticles Loaded on Activated Carbon: A Response Surface Methodology Approach. J. Taiwan Inst. Chem. Eng. 2015, 53, 80-91. [CrossRef]

81. Özacar, M.; Şengil, İ.A. Application of Kinetic Models to the Sorption of Disperse Dyes onto Alunite. Colloids Surf. A Physicochem. Eng. Asp. 2004, 242, 105-113. [CrossRef]

82. Girish, C.; Murty, V.R. Mass Transfer Studies on Adsorption of Phenol from Wastewater using Lantana Camara, Forest Waste. Int. J. Chem. Eng. 2016, 2016. [CrossRef]

83. Okoye, A.; Ejikeme, P.; Onukwuli, O. Lead Removal from Wastewater using Fluted Pumpkin Seed Shell Activated Carbon: Adsorption Modeling and Kinetics. Int. J. Environ. Sci. Technol. 2010, 7, 793-800. [CrossRef]

84. Saxena, M.; Sharma, N.; Saxena, R. Highly Efficient and Rapid Removal of a Toxic Dye: Adsorption Kinetics, Isotherm, and Mechanism Studies on Functionalized Multiwalled Carbon Nanotubes. Surf. Interfaces 2020, 21, 100639. [CrossRef]

85. Langmuir, I. The Adsorption of Gases on Plane Surfaces of Glass, Mica and Platinum. J. Am. Chem. Soc. 1918, 40, 1361-1403. [CrossRef]

86. Freundlich, H. Over the Adsorption in Solution. J. Phys. Chem. 1906, 57, 1100-1107.

87. Munagapati, V.S.; Kim, D.-S. Equilibrium Isotherms, Kinetics, and Thermodynamics Studies for Congo Red Adsorption using Calcium Alginate Beads Impregnated with Nano-Goethite. Ecotoxicol. Environ. Saf. 2017, 141, 226-234. [CrossRef]

88. Namasivayam, C.; Senthilkumar, S. Recycling of Industrial Solid Waste for the Removal of Mercury (II) by Adsorption Process. Chemosphere 1997, 34, 357-375. [CrossRef]

89. Aljeboree, A.M.; Baqir, S.J.; Alkaim, A.F. Experimental Studies of Thermodynamics Parameters: As a Model Adsorption and Removal of TEXTILE. J. Phys. Conf. Ser. 2020, 012099. [CrossRef]

90. Karakuş, S.; Şişmanoğlu, S.; Akdut, G.; Ürk, Ö.; Şişmanoğlu, E.T.T.; Kilislioğlu, A. Removal of Basic Blue 3 from the Aqueous Solution with Ternary Polymer Nanocomposite: Swelling, Kinetics, Isotherms and Error Function. J. Chem. Soc. Pak. 2017, 39, 17-25.

91. Crini, G.E.; Gimbert, F.; Robert, C.; Martel, B.; Adama, O.; Morin-Crini, N.; De Giorgi, F.; Badot, P.-M. The Removal of Basic Blue 3 from Aqueous Solutions by Chitosan-Based Adsorbent: Batch Studies. J. Hazard. Mater. 2008, 153, 96-106. [CrossRef] [PubMed]

92. Taşar, Ş.; Kaya, F.; Özer, A. Adsorption of CI Basic Blue 3 Dye Molecules from Aqueous Media by Sulfuric Acid-Activated Montmorillonite Mineral. J. Turk. Chem. Soc. Chem. Eng. 2017, 1, 1-16.

93. Ong, S.-T.; Tan, S.-Y.; Khoo, E.-C.; Lee, S.-L.; Ha, S.-T. Equilibrium Studies for Basic Blue 3 Adsorption onto Durian Peel (Durio Zibethinus Murray). Desalin. Water Treat. 2012, 45, 161-169. [CrossRef]

94. Bârsănescu, A.; Buhăceanu, R.; Dulman, V. Removal of Basic Blue 3 by Sorption onto a Weak Acid Acrylic Resin. J. Appl. Polym. Sci. 2009, 113, 607-614. [CrossRef] 
95. Tenno, T.; Rikmann, E.; Zekker, I.; Tenno, T. Modelling the Solubility of Sparingly Soluble Compounds Depending on Their Particles Size. Proc. Est. Acad. Sci. 2018, 67, 300-302. [CrossRef]

96. Zekker, I.; Tenno, T.; Selberg, A.; Uiga, K. Dissolution Modeling and Experimental Measurement of CaS- $\mathrm{H}_{2} \mathrm{O}$ Binary System. Chin. J. Chem. 2011, 29, 2327-2336. [CrossRef]

97. Tenno, T.; Rikmann, E.; Uiga, K.; Zekker, I.; Mashirin, A.; Tenno, T. A Novel Proton Transfer Model of the Closed Equilibrium System $\mathrm{H}_{2} \mathrm{O}-\mathrm{CO}_{2}-\mathrm{CaCO}_{3}-\mathrm{NH}_{\mathrm{X}}$. Proc. Est. Acad. Sci. 2018, 4017, 2. [CrossRef] 